\title{
The Yin and Yang of Type I IFNs in Cancer Promotion and Immune Activation
}

\author{
Martina Musella ${ }^{1, *}$, Claudia Galassi ${ }^{1}$, Nicoletta Manduca ${ }^{1}$ and Antonella Sistigu ${ }^{1,2, *}$ \\ 1 Dipartimento di Medicina e Chirurgia Traslazionale, Università Cattolica del Sacro Cuore, 00168 Rome, Italy; \\ claudia.galassi@unicatt.it (C.G.); nicomandu123@gmail.com (N.M.) \\ 2 Tumor Immunology and Immunotherapy Unit, IRCCS Regina Elena National Cancer Institute, \\ 00144 Rome, Italy \\ * Correspondence: martina.musella@unicatt.it (M.M.); antonella.sistigu@unicatt.it (A.S.); \\ Tel.: +39-0649904452 (M.M.); +39-0649904457 (A.S.)
}

Simple Summary: The crucial immune stimulatory functions exerted by Type I Interferons (IFNs) in cancer settings have been not only widely demonstrated during the last fifty years but also recently harnessed for therapy. However, depending on the dose and timing, and the downstream induced signatures, Type I IFNs can and do foster cancer progression and immune evasion. Dysregulations of Type I IFN signaling cascade are more and more frequently found in the tumor microenvironment, representing critical determinants of therapeutic innate and adaptive resistance to several anticancer treatments. Understanding when and through which genetic signatures Type I IFNs control or promote cancer growth is extremely urgent in order to prevent and by-pass the deleterious clinical effects and develop optimized innovative (combinatorial) strategies for an effective cancer management.

Citation: Musella, M.; Galassi, C.; Manduca, N.; Sistigu, A. The Yin and Yang of Type I IFNs in Cancer Promotion and Immune Activation. Biology 2021, 10, 856. https:// doi.org/10.3390/biology10090856

Academic Editors: Alessandra Soriani and Alessandra Zingoni

Received: 1 August 2021

Accepted: 27 August 2021

Published: 1 September 2021

Publisher's Note: MDPI stays neutral with regard to jurisdictional claims in published maps and institutional affiliations.

Copyright: (c) 2021 by the authors. Licensee MDPI, Basel, Switzerland. This article is an open access article distributed under the terms and conditions of the Creative Commons Attribution (CC BY) license (https:// creativecommons.org/licenses/by/ $4.0 /)$.

\begin{abstract}
Type I Interferons (IFNs) are key regulators of natural and therapy-induced host defense against viral infection and cancer. Several years of remarkable progress in the field of oncoimmunology have revealed the dual nature of these cytokines. Hence, Type I IFNs may trigger anti-tumoral responses, while leading immune dysfunction and disease progression. This dichotomy relies on the duration and intensity of the transduced signaling, the nature of the unleashed IFN stimulated genes, and the subset of responding cells. Here, we discuss the role of Type I IFNs in the evolving relationship between the host immune system and cancer, as we offer a view of the therapeutic strategies that exploit and require an intact Type I IFN signaling, and the role of these cytokines in inducing adaptive resistance. A deep understanding of the complex, yet highly regulated, network of Type I IFN triggered molecular pathways will help find a timely and immune"logical" way to exploit these cytokines for anticancer therapy.
\end{abstract}

Keywords: Type I Interferons; cancer; immunoediting; anticancer therapy; therapy resistance

\section{Introduction}

In the 1990s, the "danger theory" proposed by Polly Matzinger and colleagues upset the traditional view of immunity as response to solely alien microbes and molecules [1]. Henceforth, it seemed clear that immune responses can be triggered by alarm signals released by the body's own cells following changes in tissue and organ homeostasis or integrity, as it happens during cancer and viral infection. Intriguingly, antiviral and antitumor immunity share common cell-autonomous responses driven by the emission of danger signals, best known as damage-associated molecular patterns (DAMPs), which actively contribute to the establishment of a productive and long-lasting immune response allowing to clear cancer cells and viral invaders [2]. Among the many DAMPs, cell free nucleic acids emerge as key players in the orchestration of both innate and adaptive immune responses [3,4]. Indeed, during cancer cell immunogenic cell death, cell free RNAs were shown to trigger an acute production of Type I Interferons (IFNs) by dying cancer cells. 
Type I IFNs then activate an autocrine and paracrine circuit that leads to the production of a plethora of interferon stimulating genes (ISGs), among which the CXC-chemokine ligand 10 (CXCL10) acts as a potent chemoattractant for immune cells. Such Type I IFN signature, so-called "viral mimicry", on cancer cells was considered a hallmark for the full-blown efficacy of various anticancer treatments [3].

IFNs are a family of pleiotropic immunomodulatory cytokines originally identified as factors capable of interfering with viral replication [5]. Over the years, IFNs were endowed with a plethora of other activities, encompassing a detrimental involvement in autoimmune diseases, metabolic syndromes, and cancer, which make the study of IFN biology crucial for human health and disease. So far, three classes of IFNs (i.e., Type I, Type II, and Type III) were described and distinguished on the basis of upstream stimuli, producer cell type, molecular structure, cognate receptor, signaling complex, and molecular function [6].

Type I IFNs constitute the largest IFN class [7]. The human genome encodes 17 different Type I IFNs, including 13 subtypes of partially (about 70-80\%) homologous IFN- $\alpha$, and single IFN- $\beta$, IFN- $\varepsilon$, IFN- $\kappa$, and IFN- $\omega$ with lower homology $(30-50 \%)[8,9]$. Type I IFN subtypes are produced by all nucleated cells in the body and bind the same heterodimeric cell-surface receptor termed IFN $-\alpha / \beta$ receptor (IFNAR), formed by the IFNAR1 and IFNAR2 chains, thus triggering the expression of hundreds-to-thousands ISGs $[10,11]$. Type II IFN family has only one member, IFN- $\gamma$, a cytokine that is primarily produced by immune cells, specifically innate-like lymphocyte populations, such as natural killer (NK) cells and innate lymphoid cells (ILCs), and adaptive immune cells, such as T helper $1\left(\mathrm{~T}_{\mathrm{H}} 1\right)$ cells and $\mathrm{CD}^{+}$cytotoxic $\mathrm{T}$ lymphocytes (CTLs). IFN- $\gamma$ signals through the IFN- $\gamma$ receptor (IFNGR) consisting of the IFNGR1 and IFNGR2 subunits and expressed on most, and almost all, cell types [12]. Type III IFNs are the latest class to be described and include up to four members in humans: IFN- $\lambda 1$, IFN- $\lambda 2$, and IFN- $\lambda 3$, also known as interleukin (IL)-29, IL28-A, and IL-28B, respectively, and IFN- $\lambda 4$ [13]. Their peculiarity is to be structurally similar to IFN- $\gamma$ but functionally identical to IFN- $\alpha / \beta$. Type III IFNs essentially exert their biological activities on epithelial and immune cells by engaging a receptor complex composed of the IFNLR1 (also known as IL-28AR) and the IL-10R2 chains [14].

In this review, we focus on Type I IFNs. We first provide a global description of Type I IFN production and signaling pathways and then we explore their dual and complex role in the evolving tumor-host relationship, while summarizing the use and the function of Type I IFNs in oncology and emphasizing the ability of these cytokines to induce cancer adaptive resistance and immune evasion.

\section{Type I IFNs: A Complex Signaling Network}

Type I IFNs are considered as the core IFN species in all vertebrates. Evolutionary pressure has so deeply shaped these cytokines that genes encoding for Type I IFNs and their receptors were extensively duplicated, and, especially in mammals, they have gradually lost intronic regions [15]. It is well documented that Type I IFNs constitute the heart of a complex cell signaling system made up of upstream and downstream components and instructed to provide an effective forward line of cell-autonomous defense against foreign pathogens and inner dangers (e.g., cancer cells).

\subsection{Upstream Triggers of Type I IFNs}

As reported above, Type I IFNs are universally produced in the body. More specifically, IFN- $\beta$ is released by all nucleated cell types, whereas IFN- $\alpha$ is primarily secreted by a unique subset of immune cells, known as plasmacytoid dendritic cells (pDCs) [16]. Under physiological conditions, small amounts of Type I IFNs are constitutively released. This results in a low tonic IFN signaling responsible for tissue homeostasis and "readiness" to tackle environmental challenges $[17,18]$. In the face of danger signals, as during viral infection and cancer, Type I IFN production rapidly increases following the stimulation of a wide array of innate immune sensors, known as pattern recognition receptors 
(PRRs), which recognize and respond to exogenous pathogen-associated molecular patterns (PAMPs) and autologous DAMPs, thus providing a first line of host defense and preserving homeostasis [19-21]. Currently identified PRRs reside in different subcellular compartments of immune and non-immune cells, such as the plasma membrane, and the cytosol or endosomal compartments [22], and include Toll-like receptors (TLRs), Retinoic acid-inducible gene I (RIG-I)-like receptors (RLRs), nucleotide-binding oligomerization domain (NOD)-like receptors (NLRs), and different DNA sensors [23]. PRR structures and signaling pathways were recently and extensively reviewed elsewhere [24]. Although viral or autologous nucleic acids (sensed by cytosolic and endosomal PRRs) are the key inducers of Type I IFNs, a minority of other molecules, e.g., bacterial lipopolysaccharide (LPS), viral proteins, lipoproteins, peptidoglycans, and mislocalized or misprocessed endogenous proteins, are also recognized via surface PRRs $[22,25,26]$ and lead to Type I IFN-related innate immune responses [23,24].

Briefly, at the cell surface, TLR1, TLR2, TLR4, TLR5, and TLR6 sense bacterial cell wall components, such as lipoproteins, LPS, and flagellin [27-30]. Within the endosomal compartment, Type I IFN production is mainly evoked via TLR3, TLR7, TLR8, and TLR9 responding to double-stranded RNA (dsRNA), single-stranded RNA (ssRNA), and unmethylated CpG DNA, respectively [31-34]. Noteworthy, among the cytosolic RNA sensors capable of eliciting Type I IFNs, there are the DExD/H box RNA helicases RIG-I and melanoma differentiation-associated gene (protein) 5 (MDA5, also known as interferoninduced helicase $\mathrm{C}$ domain-containing protein 1 (IFIH1)) and the NOD-containing protein 2 (NOD2). RIG-I and MDA5 are RLRs primarily sensing dsRNA or 5'ppp-RNA [35-37], whereas NOD2 is a NLR that recognizes ssRNA $[38,39]$. Immune sensing of cytosolic DNA (being either xenogeneic from intracellular pathogens, exogenous from dying cells, or endogenous resulting from mitochondrial breakdown, DNA damage, and replication stress) is driven by a multitude of cytoplasmic sensors, including the Z-DNA binding protein 1 (ZBP1; also known as DAI) [40] and the nucleotidyltransferase cyclic GMP-AMP (cGAMP) synthase (cGAS) [41-43]. Several other proteins described to respond to cytoplasmic DNA encompass the PYHIN family members absent in melanoma 2 (AIM2) $[44,45]$ and IFN- $\gamma-$ inducible protein 16 (IFI16) [46,47], DExH-box helicase 9 (DHX9) [48], DEAH-box helicase 36 (DHX36) [49], and the DEAD-box helicase 41 (DDX41) [50], as well as the nucleases MRE11 homolog, double strand break repair nuclease (MRE11) [51], and the three prime repair exonuclease 1 (TREX1) [52], all elegantly described in Reference [53].

Overall, once activated, these receptors engage redundant signal transduction cascades that involve adapter proteins and lead to the transcriptional induction of diverse immune genes, including those encoding for Type I IFNs [24]. Specifically, signaling immediately downstream of TLRs, RIG-I, MDA5, DHX9, and DHX36 is largely conveyed through adaptor proteins, such as toll-like receptor adaptor molecule 1 (TICAM1, best known as TRIF), mitochondrial antiviral signaling adaptor (MAVS), or MYD88 innate immune signal transduction adaptor (MYD88) [54,55]. At odds, cGAS, DDX41, IFI16, and, at least in some settings, ZBP1 stimulation activates the stimulator of interferon genes (STING) [24]. The association of PRRs with their adaptors usually converges in the activation of the IKB kinase$\varepsilon(\mathrm{IKK} \varepsilon)$ and TANK-binding kinase 1 (TBK1) complex, which, in turn, phosphorylates and activates key members of the IFN regulatory factor (IRF) family, such as IRF3 and IRF7, and the transcriptional factors nuclear-factor- $\mathrm{KB}(\mathrm{NF}-\mathrm{kB}$ ) and activated protein 1 (AP1) [56]. Once recruited, these transcriptional factors translocate to the nucleus, where IRF3, NF- $\mathrm{kB}$, and AP1 trigger a first wave of IFN- $\beta$ production [57-59], commonly observed within $1-4 \mathrm{~h}$ after stimulation, while IRF7 regulates a positive feedback loop leading to a secondary burst of IFN- $\alpha$ secretion [60]. It is worth considering that Type I IFN genes go through a tight and context-dependent post-transcriptional regulation via RNA regulatory elements (e.g., microRNAs) [61]. Hence, production of Type I IFN-coding messenger RNAs (mRNAs) may not always guarantee their protein level generation [62]. Interestingly, Type I IFN production can also be contextually induced by cytokines generally produced during 
inflammation, e.g., tumor-necrosis factor (TNF), macrophage colony stimulating factor (M-CSF), and receptor activator of NF-kB ligand (RANKL) [63,64].

\subsection{Downstream Effectors of Type I IFNs}

Once released, Type I IFNs act in an autocrine and paracrine manner, and through the IFNAR receptor, give rise to "canonical" and "non-canonical" signaling pathways which directly regulate the transcription of a large set of ISGs [65]. While sharing the same highly evolutionary conserved and ubiquitous receptor, Type I IFN subtypes differ for their binding affinity, which inevitably affects downstream signaling and gene expression profiles [66]. More precisely, IFN- $\alpha$ subtypes show low affinity to both IFNAR1 and IFNAR2 chains (about 1-5 $\mu \mathrm{M}$ and $200 \mathrm{nM}$ affinity, respectively), whereas IFN- $\beta$ binding is much tighter (100 $\mathrm{nM}$ and $0.2 \mathrm{nM}$ affinity, respectively) $[67,68]$.

Upon Type I IFN binding, IFNAR1 and IFNAR2 get into close proximity and dimerize. This causes the reciprocal trans-phosphorylation and subsequent activation of the receptor-associated proteins tyrosine kinase 2 (TIK2) and Janus Kinase 1 (JAK1) [69,70]. In the "canonical" Type I IFN signaling pathway, this results in the generation of docking sites for the recruitment of cytosolic $\mathrm{SH} 2$ domain-containing proteins, particularly the signal transducer and activator of transcription 1 (STAT1) and 2 (STAT2) [71,72], leading to their tyrosine phosphorylation and dimerization $[73,74]$. Phosphorylated STAT1 and STAT2 form the canonical heterodimer (pSTAT1-pSTAT2) that associates to IRF9 to complete the heterotrimeric transcriptional complex, IFN-stimulated gene factor 3 (ISGF3) [10]. Activated ISGF3 then moves to the nucleus where it binds to IFN-stimulated response elements (ISREs) within the promoter regions of ISGs. Thus, ISGs exert the immune-regulatory and antiviral actions of Type I IFNs [11,75]. As a clear proof of JAK and STAT relevance in Type I IFN signaling, mutations or loss of function of these components can predispose the host to infection, autoimmune reactions, cancer, and alterations in therapeutic responses [57]. However, accumulating evidence highlights a far more complex and heterogeneous process of activation and regulation of ISGs, thus assessing the existence of parallel "non-canonical" signaling cascades [76]. Indeed, depending on the cell type, Type I IFNs can also activate distinct STAT isomers (either phosphorylated or not) or even non-STAT pathways [65]. In this regard, following continuous exposure to low levels of IFN- $\beta$, unphosphorylated ISGF3 (U-ISGF3) complex prolonged Type I IFN responses through high intranuclear levels of U-STAT1, U-STAT2, and IRF9 [77,78]. Along with this, a body of scientific evidence suggests that transcriptional factors containing IRF9 and either STAT1 or STAT2, but not both, are implicated in controlling ISG expression $[79,80]$. In particular, a more recent study by Platanitis et al. shows that the transcriptional profile of resting-state murine macrophages is regulated by a preformed STAT2-IRF9 complex, whose generation does not require signaling by IFNAR receptor [81]. Type I IFN stimulation induces a rapid molecular switch from STAT2-IRF9 complex to ISGF3, thus "revving-up" the transcription of most ISGs [81]. Additionally, JAKs can phosphorylate and induce the formation of p-STAT1 and p-STAT3 homodimers, where the former is connected with IFN- $\gamma$-mediated signaling by binding gamma activated sequences (GAS) on DNA, and the latter indirectly inhibits pro-inflammatory IFN-mediated responses [82-84]. At the same time, Type I IFNs were also reported to signal via STAT2-STAT3 heterodimers, STAT4, a complex formed by STAT5 and CRK likeproto-oncogene adaptor protein (CrkL) and STAT6 [85-89]. To add further layers of complexity, Type I IFNs can directly or indirectly activate other signaling factors while interacting with STAT family members. MAP kinase (MAPK) and phosphoinositide 3-kinases (PI3K)/mammalian target of rapamycin (mTOR) pathways were shown to invoke ISG transcriptional activation [90-92]. In this context, Unc-51-like kinase (ULK1) was recently described to affect ISG production and Type I IFN-induced biological activity in a STAT-independent manner [93]. Other "non-canonical" molecules include Schlafen (SLFN) family members and Sirtuins, whose additional effects were examined in various solid and liquid malignancies [94-96]. In a recent study on glioblastoma, SLFN5 expression was associated with the negative regulation of STAT1-mediated Type I IFN responses and, thus, 
with the promotion of a malignant phenotype [97]. Even more, in leukemia and lymphoma cells, SIRT2 was found to induce STAT1 phosphorylation at serine 727 by deacetylating cyclin-dependent kinase 9 (CDK9) in a Type I IFN-dependent manner [96].

Owing to the importance of Type I IFN-ISG system during virus-related and unrelated diseases (such as cancer), this signaling cascade is tightly regulated in order to ensure host protection while limiting inflammation and tissue damage and preventing autoimmune responses [98,99]. Therefore, multiple layers of positive and negative feedback mechanisms control the strength and duration of Type I IFN responses. Above all, many components of upstream PRR pathways, including receptors and IRFs, are ISGs [100] Then, negative regulation of cytokine-induced signaling relies on the downregulation of cytokine receptors. Indeed, IFNAR receptors are endocytosed and degraded within minutes of their stimulation and this occurs via ubiquitination of IFNAR1 and exposure of a Tyr-based endocytic motif usually masked by Tyk2 in basal conditions [67,101,102]. Yet, when IFNAR1 is expressed at high levels, its phosphorylation, ubiquitination, and degradation are triggered in an IFN/JAK-independent manner [103]. A further feedback mechanism involves the Type I IFN-mediated induction of the ISG ubiquitin specific peptidase 18 (USP18). This protein endowed with ISG15 (a ubiquitin-like protein)-specific protease activity was shown to not be required for IFNAR desensitization but, rather, to potently interfere with the recruitment of IFNAR1 to the ternary complex by binding to IFNAR2 and STAT2, and, thus, to reduce the responsiveness to Type I IFNs [104-108]. If, on the one hand, lack of USP18 results in a persistent, strong Type I IFN signal, as shown for mouse brain that developed destructive interferonopathy [109], on the other hand, reduced USP18 levels can increase antiviral immunity [110]. Last but not least, Type-I-IFNs are also reported to inhibit their own signaling by transactivating members of the suppressor of cytokine signaling (SOCS) family [111], among which SOCS1 represents a potent inhibitor of Tyk2 [112].

All these observations could, at least in part, explain the complex nets regulating ISG expression and ensuring the broad spectrum of Type I IFN responses during infection, cancer, and inflammation.

\section{Type I IFN-Induced Genetic and Epigenetic Signatures}

Depending on their upstream stimuli and cellular source, each Type I IFN subtype induces unique and partially overlapping patterns of ISG expression, commonly referred to as "Type I IFN signatures" [11,75]. In their simplest definition, ISGs are all those genes transcriptionally activated during Type I, II, or III IFN responses, and, in humans, they approximately constitute the $10 \%$ of the genome. These genes undergo up to 100 -fold transcriptional increase depending on the IFN dose, cell lineage, and other endogenous and exogenous variables in cellular signaling [113].

Although a good portion of ISGs encodes antiviral proteins (e.g., MX1, MX2, MXA, OAS1, IFI6) [114], a significant one is responsible for the various immune-modulatory activities of Type I IFNs. It is not surprising that the most notorious ISGs include chemokines (e.g., CCL5, CXCL10, CCL3, CCL9,CXCL9, CXCL11) which recruit immune inflammatory cells, apoptosis inducers or modulators (e.g., FAS and its ligand FASL, XIAP-associated factor (XAF1), galectin 9, TNF-related apoptosis-inducing ligand (TRAIL), ISG12, death-activating protein (DAP) kinase, phospholipid scramblase), genes required for major histocompatibility complex (MHC)-I/II based antigen presentation pathways, anti-angiogenic proteins (e.g., STAT1, promyelocytic leukemia protein (PML), guanylate-binding protein 1 and 2 (GBP1/2), ISG20), and cluster of differentiation (CD) molecules (e.g., CD40, CD80) [115,116]. A comprehensive list of ISGs is available at http:/ / interferome.org/interferome/home.jspx. accessed on 1 August 2021).

As is so often the case, the system is still more complex than it seems. Several ISGs are direct targets of IRF1, IRF3, IRF7, NF- $\mathrm{kB}$, or IL-1 potentially leading to multiple pathways by which a single ISG can be induced [117]. Another crucial aspect that should not be neglected is that some ISGs are basally expressed in addition to being IFN-inducible, while others appear to be expressed only during an IFN response [76]. Yet, although 
we typically consider ISGs as IFN-inducible protein coding mRNAs, it is important to recognize that IFNs also induce myriad of noncoding RNAs, including long noncoding RNAs and microRNAs (i.e., micro-RNA-106 or miR-106, miR-16) [118,119]. Moreover, a fraction of genes is also repressed during Type I IFN stimulation, and these were denoted as interferon-repressed genes (IRGs or IRepGs) [120,121].

Despite the fact that the nature and the underlying molecular mechanisms of a large majority of ISGs are still unknown, Type I IFN genetic signatures have been extensively investigated in the pathogenesis of several autoimmune diseases, including systemic lupus erythematosus, rheumatoid arthritis, systemic sclerosis, and interferonopathies, in general $[122,123]$. Remarkably, as we are going to discuss in detail in the next sections, these signatures have earned relevant achievements in cancer because of being potentially associated with favorable patient prognosis $[124,125]$ or paradoxically with therapeutic tumor resistance [126,127].

Nonetheless, it has now become clear that Type I IFNs can also induce the so-called "IFN epigenomic signatures" by directly reshuffling chromatin structure and gene expression [128]. The epigenome or 'epigenomic landscape' is defined as the whole and dynamic genome pattern of histone and DNA modifications, chromatin conformation, and transcription factor binding that regulates cell-specific gene expression profiles and responsiveness to environmental stimuli [129]. Emerging scientific evidence suggests that Type I IFNs induce extensive remodeling of the epigenome by activating new enhancers (termed latent enhancers), disassembling others, and creating chromatin "bookmarks" that de facto modulate chromatin accessibility to signal-activated transcription factors and the whole transcriptional machinery to gene regulatory elements [130,131]. IFN epigenomic signatures seem to be mediated by IFN-activated STATs and by de novo-induced transcription factors, such as IRFs, which bind gene-regulatory elements and recruit chromatinremodeling enzymes [128]. Interestingly, all these changes not only affect ISGs but also occur at regulatory elements of non-ISGs, including canonical targets of the transcription factor NF- $\mathrm{kB}$ that encode inflammatory molecules involved in the priming of immune cells, tolerance and the training of innate immune memory [132]. In particular, over the last few years, the phenomenon of trained immunity or innate immune memory is attracting increasingly more scientific interest [133]. Accordingly, the engagement of some innate immune pathways, such as Type I IFNs, can induce a downstream global epigenomic reprogramming that, although it does not involve permanent genetic changes (such as mutations and recombinations occurring in adaptive immune responses), sustains changes in gene expression and cell physiology responsible for mounting resistance and a stronger secondary reaction to reinfections [133].

Supporting this idea, a comprehensive epigenomic study in human macrophages showed that Type I IFNs potentiated TNF inflammatory function by "priming" chromatin and increasing the amount of trimethylated histone H3 Lys 4 (H3K4me3) at the regulatory elements of genes encoding for inflammatory mediators [132]. The presence of such altered chromatin states and histone bookmarks that are stable over time was found to induce the sequential occupancy of these genomic locations by IRFs and NF-kB and, thus, to enhance their transcription and responsiveness to subsequent environmental challenges [132]. Accordingly, Kamada and colleagues recently and elegantly demonstrated that IFN- $\beta$ stimulation confers transcriptional memory to fibroblasts, which was attributed to the faster and greater recruitment of p-STAT1 and RNA polymerase II (Pol II) on ISGs and to the acquisition of chromatin marks by H3.3 and H3K36 trimethylation [131].

Overall, Type I IFN-induced epigenomic changes can last for days to weeks and, thus, persist beyond the period of Type I IFN expression and upstream JAK-STAT signaling $[130,134]$. Such persistence confers transcriptional memory and sustains the expression of ISGs. Conversely, for non-ISGs, although Type I IFN-induced epigenomic changes are often transcriptionally silent, the current model posits that such bookmarking alters the way these genes respond to subsequent stimulation [128]. Since a Type I IFN epigenomic signature can increase and sustain immune inflammatory responses, it seems quite obvious 
that innate immune chromatin reprogramming can have deleterious effects in the pathogenesis of autoimmune and cancerous diseases [133]. In light of this, further investigations into Type I IFN genetic and epigenetic signatures for individual cell types are required to decipher the molecular mechanisms of chromatin modifications and gene expression, in order to provide novel biomarkers of disease pathogenesis and to develop new powerful strategies for autoimmune disorder and cancer therapy.

\section{Type I IFNs and Cancer: A Troubled Relationship}

During the past few decades, the pleiotropic antitumor functions exerted by Type I IFNs became universally acknowledged [135]. Regardless of their source, Type I IFNs play a pivotal role in the dynamic relationship between the host immune system and cancer by directly and indirectly affecting the different aspects of tumor generation, progression, and treatment. In fact, although generally considered as pro-inflammatory cytokines, Type I IFNs are reported to either restrain or promote tumor growth, and this depends on the duration and intensity of the transduced signaling and/or the unleashed ISG profile in the tumor microenvironment (TME) [136], as further discussed below.

\subsection{Type I IFNs and Cancer Immunosurveillance}

Type I IFN tumor intrinsic role is well documented in many animal models (see Box 1) and is associated with the ability of these cytokines to regulate a plethora of biological processes including cell proliferation, differentiation, survival, and invasion [137]. Specifically, Type I IFNs can affect cancer cell proliferation and exert a cytostatic action both by prolonging or blocking the cell cycle $[138,139]$. Indeed, Type I IFNs are reported to upregulate the cyclin dependent kinase inhibitors 1A, 1B, and 2B [140] (CDKN1A, CDKN1B, and CDKN2B, which are best known as p21, p27, and p15, respectively), which lead to a delay of the G1-S phase transition [138,140-142], and to activate p38 MAPK [143] or CrkL signaling pathways, the latter, in turn, interacting with the tumor suppressor RAP1A, member of RAS oncogene family (RAP1A) [89,144]. Type I IFNs can also regulate apoptosis by modulating both the extrinsic (death receptor-mediated) and the intrinsic (mitochondrial) routes [145-147]. Accordingly, some of the best known apoptotic-related genes, such as FAS, FASL, XAF-1, caspase-4, caspase-8, EIF2AK2 (best known as protein kinase R, PKR), galectin-9, and 2'-5'-oligoadenylate synthetase (OAS), particularly the 9-2 isozyme, are ISGs [148]. Furthermore, a recent breakthrough by Frank and colleagues established an interesting link between mitotic cell cycle arrest and IFN- $\beta$ in the promotion of necroptosis, a programmed form of necrosis, in apoptosis-resistant cancer cells through the phosphorylation of receptor interacting serine/threonine kinase 3 (RIPK3 also known as RIP3) [149]. Concerning the direct antitumoral functions of Type I IFNs, the induction of cell senescence must be mentioned, as well. Indeed, as a result of the strong genomic instability and DNA damage, often ascribed to cancer cells, Type I IFNs are produced and drive the development of oncogene-induced senescence [150]. In this context, the engagement of the cytosolic cGAS-STING signaling pathway seems to be essential for the establishment of such important tumor-suppressive program [151,152].

Beyond their cytostatic and cytotoxic activities, Type I IFNs play a fundamental role in coordinating a harmonized immune response against malignant cells. Pioneering studies performed by Brouty-Boye and colleagues demonstrated that the exogenous administration of crude Type I IFN preparations increased the survival of mice affected by lymphocytic leukemia, regardless of the intrinsic sensibility of cancer cells to IFNs [153]. Since then, multiple studies in both human and mice tumor models highlighted the importance of these cytokines in influencing each step of the cancer immunity cycle $[135,154]$. In the early 1990s, Ferrantini's group performed studies with different IFN $\alpha 1$ gene transduced cancer cells (Friend leukemia, B16 melanoma, and TS/A mammary carcinoma) in syngeneic immunocompetent mice and observed an important host-dependent tumor rejection complemented by the development of a robust and protective antitumor immunity mediated by $C D 8^{+} T$ cells $[155,156]$. That said, Dunn et al. proved that Type I IFNs intervene in all the 
three phases of the immunoediting process as review in Reference [157], with a prominent role in the "elimination" stage [158]. By using immunocompetent mice, they specifically demonstrated that endogenous Type I IFNs were required to reject MCA-induced sarcomas and to prevent the outgrowth of primary carcinogen-induced tumors. Moreover, they also observed that several MCA-induced sarcomas from Ifnar $1^{-/}$mice were rejected in a T cell-dependent manner in wild-type $(\mathrm{Wt})$ mice, thus suggesting that tumors arising in the absence of Type I IFN responses are more immunogenic than tumors growing in IFNAR competent hosts [157]. Along similar lines, Type I IFNs exert powerful immunoregulatory effects on multiple cancer cell types (e.g., melanoma, breast, ovarian and colon cancer) by upregulating the expression of surface tumor-associated antigens [159-162] via upregulation of MHC-I and -II class molecules [163,164], thus increasing the immunogenicity of cancer cells and making them more vulnerable to immune-mediated recognition and destruction. As confirmation of their antineoplastic activity, several important studies describe Type I IFNs as negative regulators of cancer stemness. Cancer stem cells (CSCs, also known as tumor-initiating cells) represent a small immature cellular population within the tumor mass endowed with some unique properties, such as self-renew capacity, multipotency, therapy resistance, and tumorigenic and metastatic potential, that are responsible for tumor progression, recurrence, and poor prognosis $[165,166]$. A recent study reported that Type I IFNs limit CSC generation and survival, as demonstrated by the evidence that chronic abrogation of endogenous Type I IFN signaling leads to the emergence of more aggressive breast ALDH1 ${ }^{+}$CSCs in HER2/neu transgenic mice [167]. In accordance, Doherty et al. obtained similar results when studying the role of IFN- $\beta$ on triple-negative breast CSCs [168]. In support of this, already, in 2009, Yuki and colleagues observed how IFN- $\beta$ negatively affected proliferation, self-renewal capacity, and tumorigenesis of human glioma-initiating cells by inducing their terminal differentiation into oligodendrocytes via STAT3 activation [169]. Another interesting study also underscored the role of Type I IFNs as repressors of glioma stem-like cells (GSCs) by inhibiting their proliferation and self-renewal potential [170]. Yet, by downregulating STAT1, GSCs evade the inhibitory pressure of Type I IFNs in the TME and fuel tumor outgrowth [171]. Moreover, murine lung cancer cells transduced with Ifnb1 gene showed a significant decrease in their tumorigenic and metastatic capacity, as compared to control cells [170]. Consistent with these findings, IFN- $\alpha$ has also been reported to specifically target the side population of ovarian cancer cells, a subset of cells endowed with stem-like properties [172]. However, as we are going to explain better in the next paragraph, the contribution of Type I IFN signaling on tumor heterogeneity and CSC maintenance/induction is still debated and provides opposite and contradictory results.

To date, Type I IFNs have gained big attention as crucial factors boosting and bridging innate and adaptive immunity. In this regard, Type I IFNs behave as activators of multiple immune cells, including DC, macrophages, NK, T, and B cells, to promote antitumor immunity. Briefly, DCs, and particularly conventional DCs, are specialized antigen presenting cells (APCs) with the unique ability to process exogenously captured antigen for presentation on MHC-I molecules to $\mathrm{CD}^{+} \mathrm{T}$ cells. A substantial number of scientific findings highlights the importance of Type I IFN signaling in the maturation and activation of DCs by enhancing their ability to cross-prime and activate tumor-specific $\mathrm{CD} 8^{+} \mathrm{T}$ cells through the upregulation of the costimulatory molecules MHC-I, MHC-II, CD40, CD80, CD86 [173] and the retention of antigenic particles engulfed from apoptotic cells [174]. Indeed, mice lacking IFNAR1 receptors in DCs are unable to reject highly immunogenic tumor cells, and DCs from these mice display an impaired antigen cross-presentation ability [175]. Upon tumor antigen presentation, $\mathrm{CD} 8^{+} \mathrm{CTLs}$, with the help of $\mathrm{CD} 4^{+} \mathrm{T}$ cells, acquire the killing capacity for tumor elimination. Many studies have demonstrated the fundamental implication of Type I IFN signaling in the generation, proliferation, differentiation and activity of antigen activated CD8 ${ }^{+} \mathrm{T}$ cells $[176,177]$. Type I IFNs do not only promote CTL survival by increasing Bcl-XL expression and IL-2 production [178] but also contribute to their recruitment into the TME through enhanced release of the chemokines CXCL10, 
CXCL9, and CCL5 $[179,180]$. Type I IFNs also directly enhance CD8 ${ }^{+} \mathrm{T}$ cell responsiveness to cognate antigens $[181,182]$ and stimulate the acquisition of CTL effector function through activating the STAT3-Granzyme B (GzmB) pathway, thus ensuring tumor suppression [183]. While promoting $\mathrm{CD}^{+} \mathrm{T}$ cell differentiation into $\mathrm{GzmB}^{+}$effector cells, Type I IFNs concurrently seem to limit the expansion of the newly identified TCF $1^{+} \mathrm{CXCR} 5^{+}$memory and stem-like $\mathrm{CD}^{+} \mathrm{T}$ cell compartment, responsible for sustaining the ongoing $\mathrm{T}$ cell responses during chronic viral infections and cancer, and preferentially responding to anti-PD-L1 immunotherapy [184-186]. Remarkably, since human lymph nodes are protected from Type I IFN signaling, they represent the long-term reservoirs for maintenance of memory TCF $1^{\text {high }}$ $\mathrm{CD}^{+} \mathrm{T}$ cells [187]. Type I IFNs were also reported to shape $\mathrm{CD}^{+} \mathrm{T}$ cell differentiation, expansion and survival and to reinforce the Th1 lineage commitment $[188,189]$. Notably, Type I IFNs are known to dampen regulatory T cell (Treg) recruitment and activation, thus contrasting the generation of an immunosuppressive TME [190-192]. Concerning their innate immunoregulatory functions, Type I IFNs are responsible for the induction of NK cell cytotoxicity. Although mature NK cells did not require Type I IFNs for cancer surveillance [193], the loss of Type I IFN responsiveness negatively impacts on NK cell antitumor immunity and impairs primary and metastatic tumor clearance in multiple models of breast cancer [194,195]. As confirmation of their pleiotropic role in the TME, Type I IFNs also negatively regulate the accumulation and activity of myeloid-derived suppressor cells (MDSCs) [196,197], while stimulating monocyte differentiation into M1-polarized pro-inflammatory macrophages [198], and the production of various pro-inflammatory cytokines (e.g., TNF- $\alpha$, IL-1, IL-6, IL-8, IL-12, and IL-18) [199]. To establish a more complete framework, Type I IFNs also promote polarization of tumor-associated neutrophils toward an anti-tumor N1 phenotype [200], increase the cytotoxicity of $\gamma \delta \mathrm{T}$ and NKT cells, as observed in leukemia and melanoma settings [201-203], and enhance the antibody-mediated response by promoting the isotype switching in B cells [204,205].

In addition to a direct impact on immune cells, Type I IFNs have extrinsic effects on tumors by regulating their metabolism and the angiogenic process [206]. In light of their ability to impair endothelial cell proliferation and migration, to promote the infiltration $\mathrm{T}$ cells able to remodel the tumor vasculature, and to downregulate the expression of the vascular endothelial growth factor (VEGF), Type I IFNs have been longtime considered as inhibitors of angiogenesis [207,208]. Moreover, despite a detailed description is beyond the scope of this review, Type I IFNs drive the metabolic reprogramming of immune cells in the TME, thus impacting on their unique functions [209]. To give some examples, Type I IFNs simultaneously stimulate fatty acid oxidation and glycolysis in pDCs $[209,210]$, while inhibiting cholesterol synthesis in macrophages in a STING-dependent manner [211].

\subsection{Type I IFNs and Cancer Immunoescape}

At odds with the benefits of Type I IFNs in tumor control, a substantial number of scientific studies also describes pro-tumoral properties for these cytokines. Despite being classically depicted as pro-apoptotic agents, IFN- $\alpha$ and IFN- $\beta$ can induce cell survival and protect cancer cells against apoptotic stimuli by activating the NF- $\mathrm{kB}$ pathway in a wide variety of cancer types [212,213]. Type I IFNs also upregulate the survival factors MCL1, the apoptosis regulator BCL2 family member (MCL1) and interferon alpha inducible protein 6 (IFI6, best known as G1P3) in myeloma and estrogen-receptor positive breast cancer, respectively, thus promoting poor patient outcome [214,215]. Furthermore, in lung and head and neck cancers, the interferon induced transmembrane protein 1 (IFITM1) was shown to enhance in vivo tumor growth and tissue invasion at early stage [216,217].

One of the most important emerging hallmarks of cancer is the ability of cancer cells to evade immune responses. As already described above, Type I IFNs are involved in the immunoediting process, and, while intervening in the phase of "elimination", they also foster the subsequent stages of "equilibrium" and "escape". During these phases, heterogeneous and genetically unstable tumors, initially held in check by the immunosurveillance, go through a progressive and constant immune pressure culminating with 
the selection of poor immunogenic cancer cell variants able to evade immune recognition and/or destruction [158]. Coherently, aggressive tumors escaping immune control present a consistent dysregulation and, specifically, downregulation of Type I IFN production and responsiveness [116]. Along with this, Type I IFNs contribute to the generation of an immunosuppressive TME taking part to a process known as immunosubversion, during which cancer cells skew immune cells toward dysfunctional or immunosuppressive phenotypes [218]. In this scenario, Type I IFNs elicit the suppressive or tolerogenic activity of monocyte-derived DCs by promoting the expression of indoleamine 2-3'-dioxygenase (IDO) and the production of IL-10 and other anti-inflammatory mediators, thus ultimately leading to T cell response attenuation [219-221]. Type I IFNs also trigger tumor intrinsic IDO production which enhances the immunosuppressive Treg cell activity $[222,223]$ and, as they were involved in the senescence-associated secretory phenotype [224], potentiate the expression of IL-6, which high serum levels are strongly correlated with immunosuppression, accelerated disease progression and poor overall survival in a variety of cancers [225]. Moreover, prolonged Type I IFN signaling could also promote $\mathrm{T}$ cell exhaustion and hence immune resistance by stimulating the upregulation of the immune checkpoint ligand PD-L1 (best known as CD274 molecule) [226,227]. Although this evidence supports the clinical development of the combination of Type I IFNs or Type I IFN-inducing therapies with monoclonal antibodies targeting the PD-1/PD-L1 axis [228], a recent study by Jacquelot and colleagues reported that Type I IFN signaling promotes adaptive resistance to anti PD-1/PD-L1 immunotherapy by upregulating nitric oxide synthase 2 (NOS2) [229]. Type I IFNs also regulate the function of immune cells (such as tumor-associated macrophages (TAMs), neutrophils, and MDSCs) that help form the pre-metastatic niche, thus ensuring a suitable environment for tumor development and dissemination [230].

Importantly, Type I IFNs and the ISG IFN- $\alpha$-inducible protein 27 (IFI27) were associated with the process of epithelial-to-mesenchymal transition (EMT) in ovarian cancer, leading to increased cancer stemness, tumor invasiveness, and therapeutic resistance [231]. Therefore, contrarily to the CSC inhibitory role of Type I IFNs previously described, other studies point to a role of Type I IFN signaling in the generation and/or maintenance of CSCs. First, IFN- $\alpha$ was reported to foster stem-like properties in oral squamous cell carcinoma cells [232] and to affect the invasive potential of pancreatic ductal adenocarcinoma (PDAC) cells by upregulating CSC markers, such as CD24, CD44, and CD133 [233]. Similarly, IFN- $\beta$ has also been linked to cancer stemness promotion in PDAC by inducing TAM ISG15 ubiquitin like modifier (ISG15) secretion [234], which has also been related to CSC phenotype induction in nasopharyngeal carcinoma [42]. More recently, Qadir et al. found a robust connection between death receptor CD95/FAS, Type I IFN-dependent phosphorylation of STAT1 and stemness in human breast cancer and squamous carcinoma cell lines, which can, in part, explain the correlation between STAT1 activation and therapy resistance observed in these cancer cells [235]. Remarkably, the stimulation of TLR3 and RIG-I induces in somatic cells an innate epigenetic signature which is associated to a process known as "transflammation" [236], involving chromatin remodeling and subsequent nuclear reprogramming, cell plasticity, pluripotency, and even malignant transformation $[237,238]$. In line with these data, experiments in breast cancer cells put in evidence that activation of NF- $\mathrm{KB}$ and $\beta$-catenin signaling downstream of TLR3 promoted the enrichment of a subset of cells with a CSC-like phenotype [239]. Similarly, activation of Type I IFN/IRF7 axis is critical for immunological tumor dormancy in breast cancer, an adaptive and protective mechanism that malignant cells adopt to survive stress conditions of the TME and to drive resistance to chemotherapies that preferentially target proliferating cells [240,241].

As previously outlined, a growing body of literature is interested in defining IFNrelated signatures responsible for clinical response to or therapeutic resistance of multiple cancer types. In this regard, a panel of 8 ISGs (STAT1, MX1, ISG15, OAS1, IFIT1, IFIT3, IFI44, and USP18), constituting the "IFN-related DNA damage resistance signature" (IRDS), was associated with cancer cell-intrinsic resistance to various DNA damaging agents (such as anthracyclines, taxanes, cyclophosphamide, methotrexate, and 5-fluorouracil) and 
radiation therapy, as well as with poor prognosis in a variety of malignancies, including breast cancer and glioblastoma $[126,127]$. Notably, IFN- $\beta$ was endowed with the capability to directly upregulate the expression of IRDS genes via U-STAT1 and IRF9 and, thus, to cause resistance to DNA damage and radiotherapy [78].

On the whole, these observations lend further support to the double-edge sword of Type I IFNs in the context of cancer, exerted by controlling tumor growth and promoting tumor escape (as summarized in Figure 1). In this regard, abundant hi-profile literature associated this dichotomy to the duration and intensity of Type I IFN signaling [98,242]. Specifically, acute induction of Type I IFNs, as during immunogenic chemotherapy, induces strong and productive inflammation [3,243], while chronic Type I IFN production is mainly responsible for immunosuppression and therapy resistance $[167,229]$. Indeed, the length and the strength of Type I IFN signaling are two main factors defining the patterns of ISG expression [24] and epigenetic modulation [128] and, as such, are two major determinants of either beneficial or detrimental "imprinting" on cancer and immune cells, which, thus, tip the balance toward immune control or immune escape, respectively.

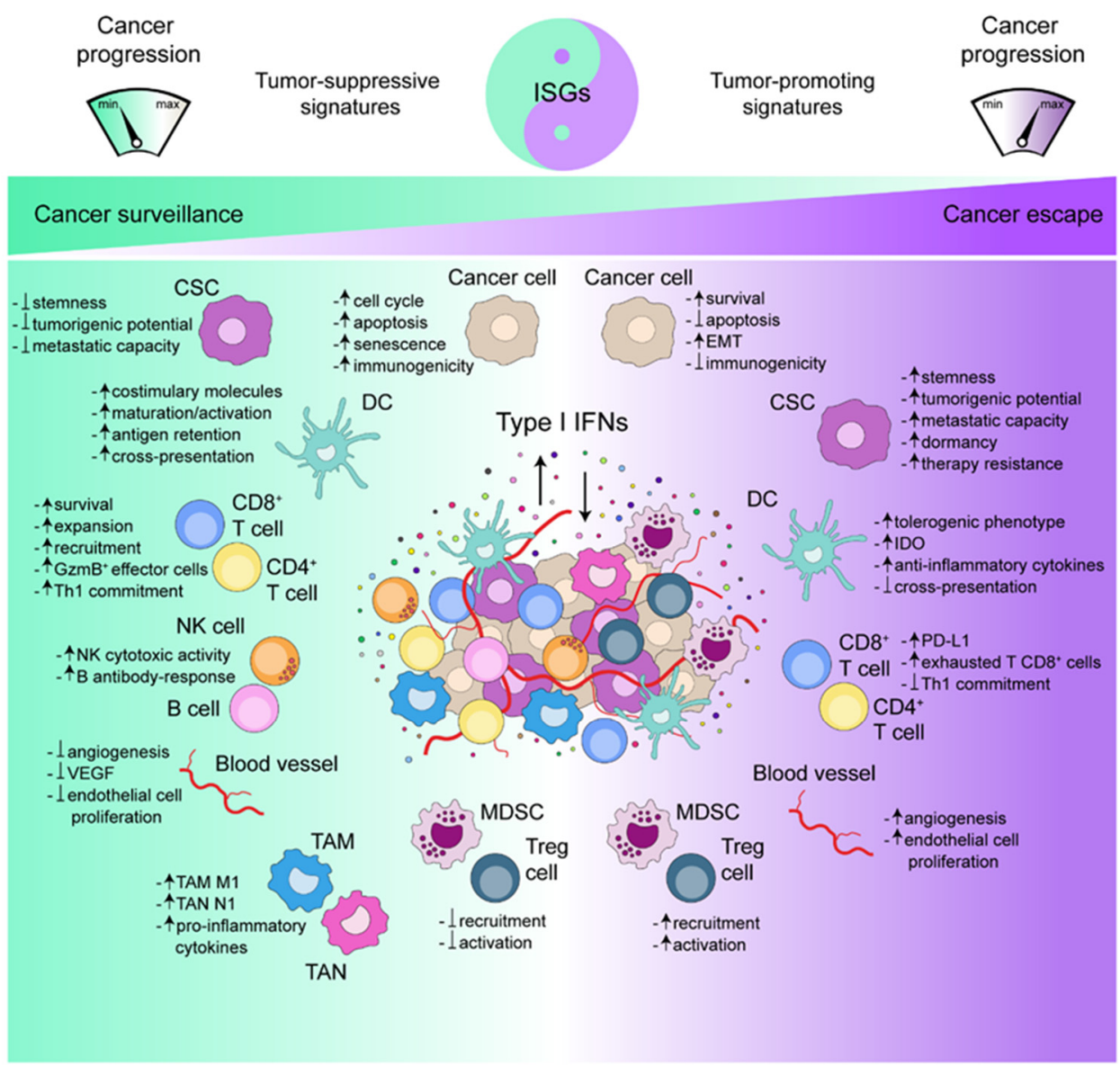

Figure 1. The yin and yang of Type I IFNs in the TME. Type I IFNs can favor cancer surveillance or cancer escape by triggering different ISGs and acting on the various cell types constituting the TME. When the tumor-suppressive genetic signatures prevail, Type I IFNs limit cancer (stem) cell expansion and angiogenesis, while promoting effective antitumor immune responses. Otherwise, the onset of tumor-promoting genetic signatures exacerbates the dark sides of Type I IFNs, thus favoring cancer progression. CSC: cancer stem cell; DC: dendritic cell; GzmB: granzyme B; NK: natural killer; VEGF: vascular endothelial growth factor, TAM: tumor-associated macrophages; TAN: tumor-associated neutrophils; Treg: regulatory T; MDSC: myeloid-derived suppressor cell; EMT: epithelial-to-mesenchymal transition; IDO: indoleamine 2-3'-dioxygenase. 
Big issues that need an urgent solution are when and through which ISGs and epigenetic signatures, Type I IFNs, do paradoxically favor tumor progression. This knowledge could help by-pass ineffective and even deleterious clinical outcomes and develop optimized, informed, and hopefully curative chemo-immunotherapies.

Box 1. Mouse models to assess Type I IFN role in cancer: principles and applications.

Current in vivo approaches to assess the relationship between cancer and immune cells, their co-evolution and the signatures involved in these dynamics, including Type I IFNs, their upstream triggers and downstream effectors, encompass (i) transplantable, (ii) carcinogen-induced, (iii) genetically engineered, and (iv) humanized mouse models. In transplantable models, inbred mice, usually from C57Bl/ 6 or BALB/c strains, are engrafted with histocompatible cancer cell lines either (i) heterotopically, generally subcute into the lower flank, which facilitates tumor growth monitoring by simple visual inspection, palpation and the use of a common caliper, or (ii) orthotopically, which mimics tissue site-specific pathology, or even (iii) systemically (intraperitoneally or intravenously), which allows to study metastatic dissemination [244]. Although displaying many advantages (e.g., synchronous and fast growth of tumors, reproducibility of data, and low costs), transplantable models are undeniably poorly "realistic" as they lack the heterogeneous and multi-step development of cancer cell variants with related effects on the parallel evolution of immune responses as it occurs during "natural" carcinogenesis [244]. Carcinogen-induced models bypass all these limitations. Indeed, these models allow the development of more realistic tumors through the local treatment with ultraviolet (UV) radiation or chemicals (mainly 7,12-dimethylbenz[a]anthracene (DMBA)/12-O-tetradecanoylphorbol 13-acetate (TPA) and 3'-methylcholanthrene (MCA)) [245]. More advanced technologies of genetic engineering let an improved mimicking of spontaneous tumorigenesis through the transgenic expression of oncogenes and/or the inactivation of tumor suppressor genes in germline cells, so-called genetically engineered mouse models (GEMMs), or, in some somatic cells, so-called non-germline GEMM (nGEMM) [246]. These models allow for studying the mechanisms of oncogenic transformation, cancer evolution and therapeutic responses. At the forefront of preclinical research in oncoimmunology, humanized mice have become increasingly refined and used as they closely recapitulate disease pathogenesis and drug testing in humans [247]. On the whole, all these mouse models have provided important insights into the cancer-host relationship also in association with the removal of essential immune-related genes. Their use have been instrumental in defining and supporting the dual role of Type I IFNs and their ISGs in cancer promotion and cancer suppression [248]. Indeed, cancer cells deficient for cardinal elements of Type I IFN production or response could be implanted inmunocompetent or nGEMM histocompatible mice to assess the cancer cell autonomous role of Type I IFNs [3]. Alternatively, transgenic mice (e.g., Ifnar ${ }^{-/-}, \mathrm{Tlr}^{-/-}$, among the others) could be either implanted with Wt cancer cells [3] or treated with carcinogens [248] or genetically engineered to develop spontaneous tumors [167] to study Type I IFN signaling on immune and even stromal cells.

Therapeutic and prophylactic procedures are the most common experimental settings applied in these models. In the therapeutic setting, tumors (either Wt or engineered to lack or overexpress a selected gene) are treated with specific drugs (either as monotherapy or in combination) and local tumor growth, systemic dissemination and mice survival are considered primary endpoints. In the prophylactic setting (mainly used to assess the immunogenic potential of drugs), in vitro killed cancer cells (either as such or loaded on syngeneic DCs) are injected in the subcute of mice, and, after a latency period of 10 to 14 days, their ability to prevent or control a rechallenge with living cancer cells of the same type represents a robust estimate of the elicitation of an adaptive, tumor specific immune response, i.e., bona fide ICD [249]. In both settings, mice showing long-term disease eradication could be further challenged to assess the specificity and memory of immune response [249].

Currently, literature is rife with descriptions of novel alternative strategies to in vivo preclinical studies, including ex vivo, in sitro, and the most innovative immune-oncology chips $[250,251]$, which are out of our scope and have been extensively reviewed elsewhere [244].

\section{Type I IFNs and Cancer Therapy: From Response to Resistance}

Type I IFNs have emerged as critical determinants of response and even resistance to several anticancer therapies, including conventional chemotherapy, radiation therapy, target therapy and immunotherapy $[116,135]$. As above comprehensively described, Type I IFNs exert a plethora of immune stimulatory effects [24], which make these cytokines pivotal regulators of immune surveillance. However, depending on the dose and timing, and the downstream induced signatures, Type I IFNs can and do promote tumor progression and immune evasion [24]. Here, we describe the lab and clinical use of Type I IFNs in oncology as we offer a view of their role in affecting the response to diverse therapeutic strategies.

\subsection{Type I IFNs and Cytotoxic Therapies}

Type I IFNs were shown to critically contribute to the induction and the perception of cancer immunogenic cell death (ICD) upon anthracycline-based chemotherapy [3]. Indeed, anthracyclines, such as viruses, lead to cancer cell-autonomous, TLR3-mediated, 
Type I IFN production, that triggers autocrine and paracrine IFNAR-dependent circuits, finally resulting in the expression of various ISGs, including CXCL10 (known to recruit innate immune cells). Of note, in several independent cohorts of breast cancer patients, the ISG MX Dynamin-Like GTPase 1 (MX1) was shown to be upregulated following anthracycline-based therapy and to predict clinical response to treatment [3]. On the whole, these observations indicate that "viral mimicry" constitutes a hallmark of successful immunogenic chemotherapy $[3,252]$. In line with these findings, blocking of IFNAR1 signaling with monoclonal antibodies, was shown to nullify the benefits of target therapy against the human epidermal growth factor receptor 2 (HER2, also known as ERBB2) and the epidermal growth factor receptor (EGFR) $[253,254]$. Type I IFNs were also shown to be an added value when combined with the ICD inducer cyclophosphamide as they induce the proliferation and activation of $C D 8 \alpha^{+} C D 11 c^{+}$DCs in mice bearing transplantable lymphomas [243]. The synergistic effects of Type I IFNs have been extensively reviewed in Reference [255] and are also effective in combination with radiation therapy. Indeed, in a pioneering study, Burnette et al. showed that local ablative radiation therapy triggers the production of IFN- $\beta$ by myeloid immune cells infiltrating B16F1 melanomas, followed by a strengthening of tumor antigen cross-presentation and treatment response in $W t$ but not Ifnar $1^{-1}$ mice [256]. Subsequent studies confirmed the role of radiation therapy-induced Type I IFNs in stimulating cancer immune surveillance $[179,257]$. In particular, in a mouse model of colorectal carcinoma, the activation of DCs following radiation therapy was shown to rely on cGAS > STING-mediated cytosolic DNA sensing [257]. In this study, the administration of recombinant IFN- $\beta$ at the tumor site was shown to restore the efficacy of radiation therapy in $\mathrm{CGas}^{-/-}$and Sting $^{-/-}$mice [257].

\subsection{Type I IFN Monotherapies}

Since the first report on their antitumor effects more than 50 years ago [258], Type I IFNs have been the subject of an intensive wave of clinical investigation, which leads to the approved used, by several regulatory agencies, of natural, unmodified recombinant, and pegylated IFN- $\alpha$ variants (Table 1), these last having longer half-life and persistent bioavailability [57,259]. However, over time Type I IFNs have been replaced by new, more efficient therapies. It is right and proper to note that Type I IFNs were used in cancer medicine when their main mechanisms of action were unknown and were conceived, at high doses, as conventional cytostatic drugs. The relevant off-target toxicity of high-dose Type I IFNs finally dictated the failure of these cytokines as clinical drugs. More recent discoveries of the immune modulatory and antiangiogenic effects of Type I IFNs, opened up a plethora of novel clinical indications, thus repositioning Type I IFN cytokines in newgeneration cancer therapy, and particularly immunotherapy [135]. Systemic administration of pegylated IFN- $\alpha 2 \mathrm{~b}$ in patients with melanoma has shown beneficial effects attributable to the induction of immune infiltration within tumor lesions $[260,261]$. A renaissance of Type I IFNs also pertains the treatment of chronic myeloid leukemias. Indeed, the use of pegylated IFN- $\alpha$ together with the tyrosine kinase inhibitor Imatinib, resulted in higher rates of clinical responses and in positive immune modulation [262-265].

More than 450 clinical trials are globally assessing the efficacy and the safety of Type I IFN formulations either as monotherapy or as adjunctive to conventional and new generation strategies (https: / / clinicaltrials.gov) (accessed date on 1 August 2021). Here, below, we offer a view of Type I IFNs in combination (immuno)therapies. 
Table 1. Type I IFN formulations for clinical use.

\begin{tabular}{|c|c|c|c|}
\hline Name & Company & Type I IFN Subtype & Indication(s) \\
\hline Alfaferone & Alfa Wassermann & $\begin{array}{c}\text { Natural leukocyte interferon } \\
\text { alpha }\end{array}$ & $\begin{array}{l}\text { Hairy cell leukemia, multiple } \\
\text { myeloma, non-Hodgkin lymphoma, } \\
\text { follicular lymphoma, chronic } \\
\text { myelogenous leukemia, malignant } \\
\text { melanoma, AIDS-related Kaposi's } \\
\text { sarcoma }\end{array}$ \\
\hline Belerofon & Nautilus Biotechnology & Interferon alpha & / \\
\hline HeberFERON & $\begin{array}{l}\text { Center for Genetic } \\
\text { Engineering and } \\
\text { Biotechnology }\end{array}$ & $\begin{array}{c}\text { Interferon } \\
\text { alpha-2b/interferon gamma }\end{array}$ & Basal cell cancer \\
\hline IFN alfa-2b XL & Flamel Technologies & Interferon alpha- $2 b$ & / \\
\hline Infergen & Amgen & Interferon alfacon- 1 & $\begin{array}{c}\text { Non-Hodgkin's lymphoma, ovarian } \\
\text { cancer }\end{array}$ \\
\hline Intron A & Biogen Idec & Interferon alpha- $2 b$ & $\begin{array}{c}\text { Chronic myeloid leukemia, } \\
\text { follicular lymphoma, hairy cell } \\
\text { leukemia, malignant melanoma, } \\
\text { multiple myeloma, non-Hodgkin's } \\
\text { lymphoma, AIDS-related Kaposi's } \\
\text { sarcoma }\end{array}$ \\
\hline Joulferon & Human Genome Sciences & Albinterferon alpha- $2 \mathrm{~b}$ & / \\
\hline Locteron & Biolex & Interferon alpha- $2 b$ & / \\
\hline Multiferon & Viragen & HuIFN-alpha & $\begin{array}{l}\text { Chronic myeloid leukemia, hairy } \\
\text { cell leukemia, malignant melanoma }\end{array}$ \\
\hline Novaferon & Genova Biotech Company & Interferon alpha & $\begin{array}{l}\text { Colorectal cancer, neuroendocrine } \\
\text { tumors, pancreatic cancer }\end{array}$ \\
\hline Pegasys & Hoffmann-La Roche & Peginterferon alpha-2a & $\begin{array}{l}\text { Malignant melanoma, renal cell } \\
\text { carcinoma }\end{array}$ \\
\hline PegIntron & Enzon Pharmaceuticals & Peginterferon alpha- $2 b$ & $\begin{array}{c}\text { Malignant melanoma, } \\
\text { cholangiocarcinoma, chronic } \\
\text { myeloid leukemia, solid tumors }\end{array}$ \\
\hline Reiferon Retard & Rhein Minapharm Biogenetics & Peginterferon alpha-2a & / \\
\hline Roferon A & Hoffmann-La Roche & Interferon alpha-2a & $\begin{array}{l}\text { Chronic myeloid leukemia, } \\
\text { cutaneous T-cell lymphoma, hairy } \\
\text { cell leukemia, Kaposi's sarcoma, } \\
\text { malignant melanoma, } \\
\text { non-Hodgkin's lymphoma, renal } \\
\text { cell carcinoma }\end{array}$ \\
\hline Sylatron & Merck & Peginterferon alpha- $2 \mathrm{~b}$ & Melanoma \\
\hline Wellferon & Glaxo Wellcome SA & Interferon alpha-n1 & $\begin{array}{l}\text { Chronic myeloid leukemia, Hairy } \\
\text { cell leukemia }\end{array}$ \\
\hline
\end{tabular}

\subsection{Type I IFNs and Immunotherapies}

Due to their key role in cancer immune surveillance, Type I IFNs are also considered essential for the effectiveness of various immunotherapies and have entered clinical testing in association with immune checkpoint inhibitors (ICIs), adoptive cell therapies (ACTs), cancer vaccines, and oncolytic virotherapies (OVs).

ICIs are considered pillars of current anticancer therapies [266]. Despite impressive clinical results, therapy resistance and disease relapse can be observed and mainly rely on cancer cell intrinsic and extrinsic factors within the TME [267]. Defects in Type I IFN signaling were shown to affect the efficacy of anti-PD1 based therapies [228,268-270]. Simi- 
larly, in mice and patients with triple negative breast cancer (TNBC), age-related immune dysfunction impairing ICI therapeutic benefits was shown to rely on decreased Type I IFN signaling [271]. Accordingly, treatment with the STING agonist 5,6-dimethylxanthenone4 -acetic acid restored the effectiveness of ICI-based therapy [271]. Consistent with these observations, a clinical trial (NCT03010176) testing the combination of the anti-PD-1 antibody Pembrolizumab with the STING agonist MK-1454, in patients with TNBC, yielded better response rates and survival. Accordingly, improved clinical responses were observed in patients with stage II and stage III melanomas treated with the anti-CTLA4 Tremelimumab combined with high-dose IFN- $\alpha 2 b$ [272].

A growing amount of evidence has given impetus to ACT as a potent antitumor tool $[273,274]$. T cells are unique in the cancer treatment arena as they directly and specifically kill cancer cells, have long-term persistence, and may be engineered to express high-avidity tumor-specific receptors. Type I IFNs were shown to interpose the processes of graft-versus-leukemia (GVL) and graft-versus-host disease (GVHD) by reducing alloreactive donor T-cell expansion, thus providing protection from CD4-dependent GVHD [275]. Of note, Katlinski et al. recently proposed a Type I IFN-related mechanism of immune escape, which affects the activity of chimeric antigen receptor (CAR) T cell transfer [276]. In more detail, colorectal cancer cells were shown to induce the degradation of IFNAR1 on CTLs, thus impairing their survival. Genetic stabilization of IFNAR1 preserved CTL viability and increased the efficacy of CAR-T targeting the fibrinogen activated protein [276].

Therapeutic cancer vaccines experienced a revival in the last decade. A deeper knowledge of tumor antigens and the development of diverse strategies of antigen delivery, helped the design of novel cancer vaccines to educate immune effector cells about what cancer cells "look like" so that they can be recognized and destroyed, thus reducing and, hopefully, avoiding non-specific or adverse reactions [277]. However, the induction of immune suppression and the acquisition of immune resistance still represent significant challenges. The importance of Type I IFNs in improving the effectiveness of cancer vaccines was provided by various studies. In particular, Fu et al. showed that the use of STING agonists in combination with irradiated GM-CSF-secreting whole-cell vaccine (socalled STINGVAX) enhance the activity of tumor-specific CTLs in diverse murine tumor models [278]. Of note, such tumor infiltrating CTLs in STINGVAX-treated mice showed a significant up-regulation of PD-L1, which suggests the possibility to combine STINGVAX with ICIs [278]. Other clinical studies in melanoma patients receiving peptide-based vaccination (Melan-A/MART-1 and NY-ESO-1) have reported an enhanced DC maturation/activation and CD8 T cell activity when the vaccine was combined with low dose IFN- $\alpha[279,280]$.

Apparently at odds with the traditional view of Type I IFNs as antiviral agents, an ensemble of recent studies have shown that Type I IFNs actively contribute to the induction of antitumor-specific responses also in the context of OV [281]. Indeed, Type I IFN signaling was shown to play a role in inducing inflammatory responses in B16 melanomas locally treated with oncolytic Newcastle disease virus combined with systemic CTLA4 blockade. Of interest, the antitumor effects of OV were appreciable also in distant (non-virally injected) tumors [281]. Similarly, the therapeutic activity of a Semliki Forest virus encoding IL-12 was reported to strongly rely on a vector-induced Type I IFN response in the host [282].

\subsection{Type I IFNs and Therapy Resistance}

Although Type I IFNs have improved the clinical outcome in specific therapeutic settings, the development of resistance represents a recurrent problem. The complexity and the magnitude of Type I IFN signaling, together with the plasticity and the heterogeneity of cancer cells and their ever-evolving cross-talk with host immune cells, leads to the insurgence of drug resistance by distinct mechanisms, that we broadly classify as (i) unresponsiveness to Type I IFNs and (ii) Type I IFN-induced resistance.

Unresponsiveness to Type I IFNs. A variety of mechanisms were described to affect the sensing of Type I IFN signals. These include: (i) degradation of IFNAR1 in cancer and 
immune cells through ubiquitination driven by the phosphorylation on serine residues. This pathway is triggered by a variety of stress- and inflammation-related signals within the TME (e.g., hypoxia [283], proinflammatory cytokines [284], and VEGF [285]) and leads to tumor progression and immune suppression by altering the expression of the ISGs IFIT2, IRF7, MX2, and USP18 in cancer cells and of IL-2 in immune cells [150,276]; (ii) impairment of IFNAR1 signaling through SOCS-mediated prevention of STAT1 phosphorylation [286]; (iii) silencing or loss-of-function mutations of JAKs and STATs [157,270,287,288]; and (iv) downregulation of IRFs [289-291].

Type I IFN-induced resistance. Groundbreaking studies by Andy J Minn established the existence of an IFN-related DNA damage resistance signature (IRDS) responsible for an adaptive resistance to chemotherapy and radiation therapy [126]. Subsequent findings confirmed a role for Type I IFNs in adaptive resistance to therapy, as they induce surface PD-L1 on cancer cells [292]. However, prolonged Type I and II IFN exposure, was associated to a state of chronic resistance to anti PD-L1 therapy [227]. Such ICI resistance was described to rely on epigenomic changes on cancer cells, the expression of various ISGs (i.e., Tnfrsf14, Lgals9, MhcII, Ifit, Mx1), and induction of multiple T cell inhibitory receptor networks [227]. These findings are in line with previous reporting of a persistent Type I IFN related signature in RT-resistant squamous cell carcinomas, and breast, prostate, and glioma cells $[293,294]$. Of note, Type I IFNs were found to be required for CD95-induced stemness in cancer cells [235]. The mechanisms underlying CSC induction rely on STAT1 phosphorylation and the downstream activation of PLSCR1, USP18, and HERC8 [235]. Along similar lines, exosome transfer from stroma to cancer cells, was shown to drive RIG-I > STAT1-dependent signaling while promoting cancer stemness and therapy resistance [295]. Further confirming that Type I IFNs could stay at the pinnacle of therapy resistance, a more recent study described chemotherapy-induced activation of STING-mediated type I IFN signaling as a cell-intrinsic mechanism of cell survival and regrowth in diverse breast cancer cell lines [296]. On the whole, these works point out the need to dig deeper into viral-like signatures in cancer in order to tailor and optimize therapy. Indeed, therapeutic failure is not an option. Only a deep understanding of the players and the dynamics of cancer adaptation to therapies will help overcame resistance and reach effectiveness as the only possibility.

\section{Conclusions and Future Perspectives}

Type I IFNs are master regulators of cancer immunity as they tip the balance between cancer immune surveillance and cancer immune escape and between therapy response and therapy resistance. The complexity of Type I IFN signaling networks, and the plasticity of their downstream effects within the TME, leaves no doubt that a better understanding of the where, when, and how Type I IFNs should be induced or delivered in tumors in a way that promotes disease control, while preventing deleterious effects, will have invaluable insights in cancer management. Filling this gap of knowledge will indeed help to open the way for the development of innovative (combinatorial) strategies that will yield more effective and durable responses.

Author Contributions: Conceptualization, A.S. and M.M.; writing-original draft preparation, M.M. and A.S.; writing-review and editing, M.M., C.G., N.M. and A.S.; supervision, A.S.; funding acquisition, A.S. and M.M. All authors have read and agreed to the published version of the manuscript.

Funding: This research was funded by Associazione Italiana Ricerca sul Cancro (AIRC), grant number Start-Up 2016 \#18418 and Ministero Italiano della Salute grant number RF_GR-2013-02357273 to A.S. and AIRC/FIRC 2020 fellowship number 25558 to M.M. The APC was funded by AIRC, grant number Start-Up 2016 \#18418.

Institutional Review Board Statement: Not applicable.

Informed Consent Statement: Not applicable.

Data Availability Statement: Not applicable. 
Conflicts of Interest: The authors declare no conflict of interest.

\section{References}

1. Matzinger, P. The danger model: A renewed sense of self. Science 2002, 296, 301-305. [CrossRef]

2. Gong, T.; Liu, L.; Jiang, W.; Zhou, R. DAMP-sensing receptors in sterile inflammation and inflammatory diseases. Nat. Rev. Immunol. 2019, 20, 95-112. [CrossRef]

3. Sistigu, A.; Yamazaki, T.; Vacchelli, E.; Chaba, K.; Enot, D.P.; Adam, J.; Vitale, I.; Goubar, A.; Baracco, E.; Remédios, C.; et al. Cancer cell-Autonomous contribution of type I interferon signaling to the efficacy of chemotherapy. Nat. Med. 2014, 20, 1301-1309. [CrossRef]

4. Relja, B.; Land, W.G. Damage-associated molecular patterns in trauma. Eur. J. Trauma Emerg. Surg. 2019, 46, 751-775. [CrossRef]

5. Alick, I.; Lindenmann, J. Virus interference: I. The interferon. Proc. R. Soc. Lond. B 1957, 147, 258-267, Republished in CA Cancer J. Clin. 1988, 38, 280-290.

6. Fuertes, M.B.; Woo, S.-R.; Burnett, B.; Fu, Y.-X.; Gajewski, T.F. Type I interferon response and innate immune sensing of cancer. Trends Immunol. 2012, 34, 67-73. [CrossRef] [PubMed]

7. Swiecki, M.; Colonna, M. Type I interferons: Diversity of sources, production pathways and effects on immune responses. Curr. Opin. Virol. 2011, 1, 463-475. [CrossRef]

8. Pestka, S.; Krause, C.D.; Walter, M.R. Interferons, interferon-like cytokines, and their receptors. Immunol. Rev. 2004, $202,8-32$. [CrossRef] [PubMed]

9. $\quad$ Li, S.-F.; Gong, M.-J.; Zhao, F.-R.; Shao, J.-J.; Xie, Y.-L.; Zhang, Y.-G.; Chang, H.-Y. Type I interferons: Distinct biological activities and current applications for viral infection. Cell. Physiol. Biochem. 2018, 51, 2377-2396. [CrossRef] [PubMed]

10. Ivashkiv, L.B.; Donlin, L.T. Regulation of type I interferon responses. Nat. Rev. Immunol. 2013, 14, 36-49. [CrossRef]

11. Schneider, W.M.; Chevillotte, M.D.; Rice, C.M. Interferon-stimulated genes: A complex web of host defenses. Annu. Rev. Immunol. 2014, 32, 513-545. [CrossRef]

12. Ivashkiv, L.B. IFN $\gamma$ : Signalling, epigenetics and roles in immunity, metabolism, disease and cancer immunotherapy. Nat. Rev. Immunol. 2018, 18, 545-558. [CrossRef] [PubMed]

13. Lee, S.; Baldridge, M.T. Interferon-lambda: A potent regulator of intestinal viral infections. Front. Immunol. 2017, 8, 749. [CrossRef]

14. Ye, L.; Schnepf, D.; Staeheli, P. Interferon- $\lambda$ orchestrates innate and adaptive mucosal immune responses. Nat. Rev. Immunol. 2019, 19, 614-625. [CrossRef] [PubMed]

15. Krause, C.D.; Pestka, S. Cut, copy, move, delete: The study of human interferon genes reveal multiple mechanisms underlying their evolution in amniotes. Cytokine 2015, 76, 480-495. [CrossRef] [PubMed]

16. Björck, P.; Leong, H.X.; Engleman, E.G. Plasmacytoid dendritic cell dichotomy: Identification of IFN- $\alpha$ producing cells as a phenotypically and functionally distinct subset. J. Immunol. 2010, 186, 1477-1485. [CrossRef]

17. Gough, D.J.; Messina, N.L.; Clarke, C.J.; Johnstone, R.W.; Levy, D.E. Constitutive type I interferon modulates homeostatic balance through tonic signaling. Immunity 2012, 36, 166-174. [CrossRef] [PubMed]

18. Leviyang, S.; Strawn, N.; Griva, I. Regulation of interferon stimulated gene expression levels at homeostasis. Cytokine 2020, 126 154870. [CrossRef]

19. Bianchi, M.E. DAMPs, PAMPs and alarmins: All we need to know about danger. J. Leukoc. Biol. 2007, 81, 663-671. [CrossRef]

20. Garg, A.D.; Agostinis, P. Cell death and immunity in cancer: From danger signals to mimicry of pathogen defense responses. Immunol. Rev. 2017, 280, 126-148. [CrossRef]

21. Tang, D.; Kang, R.; Coyne, C.B.; Zeh, H.J.; Lotze, M.T. PAMPs and DAMPs: Signal 0s that spur autophagy and immunity. Immunol. Rev. 2012, 249, 158-175. [CrossRef]

22. Takeuchi, O.; Akira, S. Pattern recognition receptors and inflammation. Cell 2010, 140, 805-820. [CrossRef] [PubMed]

23. Kumar, H.; Kawai, T.; Akira, S. Pathogen recognition by the innate immune system. Int. Rev. Immunol. 2011, 30, 16-34. [CrossRef]

24. Musella, M.; Manic, G.; De Maria, R.; Vitale, I.; Sistigu, A. Type-I-interferons in infection and cancer: Unanticipated dynamics with therapeutic implications. Oncoimmunology 2017, 6, e1314424. [CrossRef] [PubMed]

25. Roers, A.; Hiller, B.; Hornung, V. Recognition of endogenous nucleic acids by the innate immune system. Immunity 2016, 44, 739-754. [CrossRef] [PubMed]

26. Tan, X.; Sun, L.; Chen, J.; Chen, Z.J. Detection of microbial infections through innate immune sensing of nucleic acids. Annu. Rev. Microbiol. 2018, 72, 447-478. [CrossRef]

27. Kawai, T.; Akira, S. The role of pattern-recognition receptors in innate immunity: Update on toll-like receptors. Nat. Immunol. 2010, 11, 373-384. [CrossRef]

28. Perkins, D.J.; Vogel, S.N. Space and time: New considerations about the relationship between toll-like receptors (TLRs) and type I interferons (IFNs). Cytokine 2015, 74, 171-174. [CrossRef]

29. Jin, M.S.; Kim, S.E.; Heo, J.Y.; Lee, M.E.; Kim, H.M.; Paik, S.G.; Lee, H.; Lee, J.O. Crystal structure of the TLR1-TLR2 heterodimer induced by binding of a tri-acylated lipopeptide. Cell 2007, 130, 1071-1082. [CrossRef]

30. Hayashi, F.; Smith, K.D.; Ozinsky, A.; Hawn, T.R.; Yi, E.C.; Goodlett, D.R.; Eng, J.K.; Akira, S.; Underhill, D.M.; Aderem, A. The innate immune response to bacterial flagellin is mediated by toll-like receptor 5. Nature 2001, 410, 1099-1103. [CrossRef]

31. Alexopoulou, L.; Holt, A.C.; Medzhitov, R.; Flavell, R.A. Recognition of double-stranded RNA and activation of NF-kappaB by toll-like receptor 3. Nature 2001, 413, 732-738. [CrossRef] [PubMed] 
32. Diebold, S.S.; Kaisho, T.; Hemmi, H.; Akira, S.; Sousa, C.R. Innate antiviral responses by means of TLR7-mediated recognition of single-stranded RNA. Science 2004, 303, 1529-1531. [CrossRef] [PubMed]

33. Hemmi, H.; Kaisho, T.; Takeuchi, O.; Sato, S.; Sanjo, H.; Hoshino, K.; Horiuchi, T.; Tomizawa, H.; Takeda, K.; Akira, S. Small anti-viral compounds activate immune cells via the TLR7 MyD88-dependent signaling pathway. Nat. Immunol. 2002, 3, 196-200. [CrossRef]

34. Hemmi, H.; Takeuchi, O.; Kawai, T.; Kaisho, T.; Sato, S.; Sanjo, H.; Matsumoto, M.; Hoshino, K.; Wagner, H.; Takeda, K.; et al. A toll-like receptor recognizes bacterial DNA. Nature 2000, 408, 740-745. [CrossRef]

35. Wu, Y.; Wu, X.; Wu, L.; Wang, X.; Liu, Z. The anticancer functions of RIG-I-like receptors, RIG-I and MDA5, and their applications in cancer therapy. Transl. Res. 2017, 190, 51-60. [CrossRef] [PubMed]

36. Yoneyama, M.; Onomoto, K.; Jogi, M.; Akaboshi, T.; Fujita, T. Viral RNA detection by RIG-I-like receptors. Curr. Opin. Immunol. 2015, 32, 48-53. [CrossRef] [PubMed]

37. Xu, X.X.; Wan, H.; Nie, L.; Shao, T.; Xiang, L.X.; Shao, J.Z. RIG-I: A multifunctional protein beyond a pattern recognition receptor. Protein Cell 2018, 9, 246-253. [CrossRef]

38. Keestra-Gounder, A.M.; Tsolis, R.M. NOD1 and NOD2: Beyond peptidoglycan sensing. Trends Immunol. 2017, 38, 758-767. [CrossRef]

39. Sabbah, A.; Chang, T.H.; Harnack, R.; Frohlich, V.; Tominaga, K.; Dube, P.H.; Xiang, Y.; Bose, S. Activation of innate immune antiviral responses by Nod2. Nat. Immunol. 2009, 10, 1073-1080. [CrossRef]

40. Wang, Z.; Choi, M.K.; Ban, T.; Yanai, H.; Negishi, H.; Lu, Y.; Tamura, T.; Takaoka, A.; Nishikura, K.; Taniguchi, T. Regulation of innate immune responses by DAI (DLM-1/ZBP1) and other DNA-sensing molecules. Proc. Natl. Acad. Sci. USA 2008, 105, 5477-5482. [CrossRef]

41. Sun, L.; Wu, J.; Du, F.; Chen, X.; Chen, Z.J. Cyclic GMP-AMP synthase is a cytosolic DNA sensor that activates the type I interferon pathway. Science 2013, 339, 786-791. [CrossRef]

42. Chen, R.H.; Du, Y.; Han, P.; Wang, H.B.; Liang, F.Y.; Feng, G.K.; Zhou, A.J.; Cai, M.Y.; Zhong, Q.; Zeng, M.S.; et al. ISG15 predicts poor prognosis and promotes cancer stem cell phenotype in nasopharyngeal carcinoma. Oncotarget 2016, 7, 16910-16922. [CrossRef]

43. Hartlova, A.; Erttmann, S.F.; Raffi, F.A.; Schmalz, A.M.; Resch, U.; Anugula, S.; Lienenklaus, S.; Nilsson, L.M.; Kroger, A.; Nilsson, J.A.; et al. DNA damage primes the type I interferon system via the cytosolic DNA sensor STING to promote anti-microbial innate immunity. Immunity 2015, 42, 332-343. [CrossRef]

44. Burckstummer, T.; Baumann, C.; Bluml, S.; Dixit, E.; Durnberger, G.; Jahn, H.; Planyavsky, M.; Bilban, M.; Colinge, J.; Bennett, K.L.; et al. An orthogonal proteomic-genomic screen identifies AIM2 as a cytoplasmic DNA sensor for the inflammasome. Nat. Immunol. 2009, 10, 266-272. [CrossRef]

45. Di Micco, A.; Frera, G.; Lugrin, J.; Jamilloux, Y.; Hsu, E.T.; Tardivel, A.; De Gassart, A.; Zaffalon, L.; Bujisic, B.; Siegert, S.; et al. AIM2 inflammasome is activated by pharmacological disruption of nuclear envelope integrity. Proc. Natl. Acad. Sci. USA 2016, 113, E4671-E4680. [CrossRef] [PubMed]

46. Stratmann, S.A.; Morrone, S.R.; van Oijen, A.M.; Sohn, J. The innate immune sensor IFI16 recognizes foreign DNA in the nucleus by scanning along the duplex. eLife 2015, 4, e11721. [CrossRef] [PubMed]

47. Jonsson, K.L.; Laustsen, A.; Krapp, C.; Skipper, K.A.; Thavachelvam, K.; Hotter, D.; Egedal, J.H.; Kjolby, M.; Mohammadi, P.; Prabakaran, T.; et al. IFI16 is required for DNA sensing in human macrophages by promoting production and function of cGAMP. Nat. Commun. 2017, 8, 14391. [CrossRef]

48. Kim, T.; Pazhoor, S.; Bao, M.; Zhang, Z.; Hanabuchi, S.; Facchinetti, V.; Bover, L.; Plumas, J.; Chaperot, L.; Qin, J.; et al. Aspartateglutamate-alanine-histidine box motif (DEAH)/RNA helicase A helicases sense microbial DNA in human plasmacytoid dendritic cells. Proc. Natl. Acad. Sci. USA 2010, 107, 15181-15186. [CrossRef]

49. Meng, J.; Liu, X.; Cao, X. A new cytosolic DNA-recognition pathway for DNA-induced inflammatory responses. Cell. Mol. Immunol. 2014, 11, 506-509. [CrossRef] [PubMed]

50. Zhang, Z.; Yuan, B.; Bao, M.; Lu, N.; Kim, T.; Liu, Y.J. The helicase DDX41 senses intracellular DNA mediated by the adaptor STING in dendritic cells. Nat. Immunol. 2011, 12, 959-965. [CrossRef] [PubMed]

51. Kondo, T.; Kobayashi, J.; Saitoh, T.; Maruyama, K.; Ishii, K.J.; Barber, G.N.; Komatsu, K.; Akira, S.; Kawai, T. DNA damage sensor MRE11 recognizes cytosolic double-stranded DNA and induces type I interferon by regulating STING trafficking. Proc. Natl. Acad. Sci. USA 2013, 110, 2969-2974. [CrossRef]

52. Vanpouille-Box, C.; Alard, A.; Aryankalayil, M.J.; Sarfraz, Y.; Diamond, J.M.; Schneider, R.J.; Inghirami, G.; Coleman, C.N.; Formenti, S.C.; Demaria, S. DNA exonuclease Trex1 regulates radiotherapy-induced tumour immunogenicity. Nat. Commun. 2017, 8, 15618. [CrossRef] [PubMed]

53. Vanpouille-Box, C.; Demaria, S.; Formenti, S.C.; Galluzzi, L. Cytosolic DNA sensing in organismal tumor control. Cancer Cell 2018, 34, 361-378. [CrossRef]

54. O'Neill, L.A.; Bowie, A.G. The family of five: TIR-domain-containing adaptors in toll-like receptor signalling. Nat. Rev. Immunol. 2007, 7, 353-364. [CrossRef] [PubMed]

55. Seth, R.B.; Sun, L.; Ea, C.K.; Chen, Z.J. Identification and characterization of MAVS, a mitochondrial antiviral signaling protein that activates NF-kappaB and IRF 3. Cell 2005, 122, 669-682. [CrossRef] 
56. Iwanaszko, M.; Kimmel, M. NF-kappaB and IRF pathways: Cross-regulation on target genes promoter level. BMC Genom. 2015, 16, 307. [CrossRef] [PubMed]

57. Borden, E.C. Interferons alpha and beta in cancer: Therapeutic opportunities from new insights. Nat. Rev. Drug Discov. 2019, 18, 219-234. [CrossRef] [PubMed]

58. Ikushima, H.; Negishi, H.; Taniguchi, T. The IRF family transcription factors at the interface of innate and adaptive immune responses. Cold Spring Harb. Symp. Quant. Biol. 2013, 78, 105-116. [CrossRef] [PubMed]

59. Liu, S.; Cai, X.; Wu, J.; Cong, Q.; Chen, X.; Li, T.; Du, F.; Ren, J.; Wu, Y.T.; Grishin, N.V.; et al. Phosphorylation of innate immune adaptor proteins MAVS, STING, and TRIF induces IRF3 activation. Science 2015, 347, aaa2630. [CrossRef]

60. Honda, K.; Takaoka, A.; Taniguchi, T. Type I interferon gene induction by the interferon regulatory factor family of transcription factors. Immunity 2006, 25, 349-360. [CrossRef]

61. Savan, R. Post-transcriptional regulation of interferons and their signaling pathways. J. Interf. Cytokine Res. 2014, 34, 318-329. [CrossRef]

62. Khabar, K.S.; Young, H.A. Post-transcriptional control of the interferon system. Biochimie 2007, 89, 761-769. [CrossRef]

63. Venkatesh, D.; Ernandez, T.; Rosetti, F.; Batal, I.; Cullere, X.; Luscinskas, F.W.; Zhang, Y.; Stavrakis, G.; Garcia-Cardena, G.; Horwitz, B.H.; et al. Endothelial TNF receptor 2 induces IRF1 transcription factor-dependent interferon-beta autocrine signaling to promote monocyte recruitment. Immunity 2013, 38, 1025-1037. [CrossRef] [PubMed]

64. Yarilina, A.; Park-Min, K.H.; Antoniv, T.; Hu, X.; Ivashkiv, L.B. TNF activates an IRF1-dependent autocrine loop leading to sustained expression of chemokines and STAT1-dependent type I interferon-response genes. Nat. Immunol. 2008, 9, 378-387. [CrossRef]

65. Mazewski, C.; Perez, R.E.; Fish, E.N.; Platanias, L.C. Type I interferon (IFN)-regulated activation of canonical and non-canonical signaling pathways. Front. Immunol. 2020, 11, 606456. [CrossRef] [PubMed]

66. Thomas, C.; Moraga, I.; Levin, D.; Krutzik, P.O.; Podoplelova, Y.; Trejo, A.; Lee, C.; Yarden, G.; Vleck, S.E.; Glenn, J.S.; et al. Structural linkage between ligand discrimination and receptor activation by type I interferons. Cell 2011, 146, 621-632. [CrossRef]

67. Schreiber, G. The molecular basis for differential type I interferon signaling. J. Biol. Chem. 2017, 292, 7285-7294. [CrossRef]

68. Lavoie, T.B.; Kalie, E.; Crisafulli-Cabatu, S.; Abramovich, R.; DiGioia, G.; Moolchan, K.; Pestka, S.; Schreiber, G. Binding and activity of all human alpha interferon subtypes. Cytokine 2011, 56, 282-289. [CrossRef]

69. Uze, G.; Schreiber, G.; Piehler, J.; Pellegrini, S. The receptor of the type I interferon family. Curr. Top. Microbiol. Immunol. 2007, 316, 71-95. [CrossRef] [PubMed]

70. Wallweber, H.J.; Tam, C.; Franke, Y.; Starovasnik, M.A.; Lupardus, P.J. Structural basis of recognition of interferon-alpha receptor by tyrosine kinase 2. Nat. Struct. Mol. Biol. 2014, 21, 443-448. [CrossRef]

71. Stark, G.R.; Darnell, J.E.J. The JAK-STAT pathway at twenty. Immunity 2012, 36, 503-514. [CrossRef] [PubMed]

72. Steen, H.C.; Nogusa, S.; Thapa, R.J.; Basagoudanavar, S.H.; Gill, A.L.; Merali, S.; Barrero, C.A.; Balachandran, S.; Gamero, A.M. Identification of STAT2 serine 287 as a novel regulatory phosphorylation site in type I interferon-induced cellular responses. $J$. Biol. Chem. 2013, 288, 747-758. [CrossRef] [PubMed]

73. Lukhele, S.; Boukhaled, G.M.; Brooks, D.G. Type I interferon signaling, regulation and gene stimulation in chronic virus infection. Semin. Immunol. 2019, 43, 101277. [CrossRef] [PubMed]

74. Stark, G.R.; Cheon, H.; Wang, Y. Responses to cytokines and interferons that depend upon JAKs and STATs. Cold Spring Harb. Perspect. Biol. 2018, 10, a028555. [CrossRef]

75. Cheon, H.; Borden, E.C.; Stark, G.R. Interferons and their stimulated genes in the tumor microenvironment. Semin. Oncol. 2014, 41, 156-173. [CrossRef] [PubMed]

76. Mostafavi, S.; Yoshida, H.; Moodley, D.; LeBoite, H.; Rothamel, K.; Raj, T.; Ye, C.J.; Chevrier, N.; Zhang, S.Y.; Feng, T.; et al. Parsing the interferon transcriptional network and its disease associations. Cell 2016, 164, 564-578. [CrossRef]

77. Cheon, H.; Stark, G.R. Unphosphorylated STAT1 prolongs the expression of interferon-induced immune regulatory genes. Proc. Natl. Acad. Sci. USA 2009, 106, 9373-9378. [CrossRef]

78. Cheon, H.; Holvey-Bates, E.G.; Schoggins, J.W.; Forster, S.; Hertzog, P.; Imanaka, N.; Rice, C.M.; Jackson, M.W.; Junk, D.J.; Stark, G.R. IFNbeta-dependent increases in STAT1, STAT2, and IRF9 mediate resistance to viruses and DNA damage. EMBO J. 2013, 32, 2751-2763. [CrossRef] [PubMed]

79. Fink, K.; Grandvaux, N. STAT2 and IRF9: Beyond ISGF3. JAK-STAT 2013, 2, e27521. [CrossRef]

80. Blaszczyk, K.; Nowicka, H.; Kostyrko, K.; Antonczyk, A.; Wesoly, J.; Bluyssen, H.A. The unique role of STAT2 in constitutive and IFN-induced transcription and antiviral responses. Cytokine Growth Factor Rev. 2016, 29, 71-81. [CrossRef]

81. Platanitis, E.; Demiroz, D.; Schneller, A.; Fischer, K.; Capelle, C.; Hartl, M.; Gossenreiter, T.; Muller, M.; Novatchkova, M.; Decker, T. A molecular switch from STAT2-IRF9 to ISGF3 underlies interferon-induced gene transcription. Nat. Commun. 2019, 10, 2921. [CrossRef]

82. Wang, W.B.; Levy, D.E.; Lee, C.K. STAT3 negatively regulates type I IFN-mediated antiviral response. J. Immunol. 2011, 187, 2578-2585. [CrossRef] [PubMed]

83. Zhao, L.J.; He, S.F.; Wang, W.; Ren, H.; Qi, Z.T. Interferon alpha antagonizes STAT3 and SOCS3 signaling triggered by hepatitis C virus. Cytokine 2016, 80, 48-55. [CrossRef] [PubMed]

84. Rauch, I.; Muller, M.; Decker, T. The regulation of inflammation by interferons and their STATs. JAK-STAT 2013, 2, e23820. [CrossRef] [PubMed] 
85. Gupta, S.; Jiang, M.; Pernis, A.B. IFN-alpha activates Stat6 and leads to the formation of Stat2:Stat6 complexes in B cells. J. Immunol. 1999, 163, 3834-3841.

86. Nguyen, K.B.; Watford, W.T.; Salomon, R.; Hofmann, S.R.; Pien, G.C.; Morinobu, A.; Gadina, M.; O'Shea, J.J.; Biron, C.A. Critical role for STAT4 activation by type 1 interferons in the interferon-gamma response to viral infection. Science 2002, 297, 2063-2066. [CrossRef]

87. Uddin, S.; Lekmine, F.; Sassano, A.; Rui, H.; Fish, E.N.; Platanias, L.C. Role of Stat5 in type I interferon-signaling and transcriptional regulation. Biochem. Biophys. Res. Commun. 2003, 308, 325-330. [CrossRef]

88. Hsu, Y.A.; Huang, C.C.; Kung, Y.J.; Lin, H.J.; Chang, C.Y.; Lee, K.R.; Wan, L. The anti-proliferative effects of type I IFN involve STAT6-mediated regulation of SP1 and BCL6. Cancer Lett. 2016, 375, 303-312. [CrossRef] [PubMed]

89. Fish, E.N.; Uddin, S.; Korkmaz, M.; Majchrzak, B.; Druker, B.J.; Platanias, L.C. Activation of a CrkL-stat5 signaling complex by type I interferons. J. Biol. Chem. 1999, 274, 571-573. [CrossRef]

90. Katsoulidis, E.; Li, Y.; Mears, H.; Platanias, L.C. The p38 mitogen-activated protein kinase pathway in interferon signal transduction. J. Interf. Cytokine Res. 2005, 25, 749-756. [CrossRef]

91. Li, Y.; Sassano, A.; Majchrzak, B.; Deb, D.K.; Levy, D.E.; Gaestel, M.; Nebreda, A.R.; Fish, E.N.; Platanias, L.C. Role of p38alpha map kinase in type I interferon signaling. J. Biol. Chem. 2004, 279, 970-979. [CrossRef] [PubMed]

92. Kaur, S.; Sassano, A.; Joseph, A.M.; Majchrzak-Kita, B.; Eklund, E.A.; Verma, A.; Brachmann, S.M.; Fish, E.N.; Platanias, L.C. Dual regulatory roles of phosphatidylinositol 3-kinase in IFN signaling. J. Immunol. 2008, 181, 7316-7323. [CrossRef] [PubMed]

93. Saleiro, D.; Mehrotra, S.; Kroczynska, B.; Beauchamp, E.M.; Lisowski, P.; Majchrzak-Kita, B.; Bhagat, T.D.; Stein, B.L.; McMahon, B.; Altman, J.K.; et al. Central role of ULK1 in type I interferon signaling. Cell Rep. 2015, 11, 605-617. [CrossRef] [PubMed]

94. Saleiro, D.; Platanias, L.C. Interferon signaling in cancer. Non-canonical pathways and control of intracellular immune checkpoints. Semin. Immunol. 2019, 43, 101299. [CrossRef]

95. Mavrommatis, E.; Fish, E.N.; Platanias, L.C. The schlafen family of proteins and their regulation by interferons. J. Interf. Cytokine Res. 2013, 33, 206-210. [CrossRef]

96. Kosciuczuk, E.M.; Mehrotra, S.; Saleiro, D.; Kroczynska, B.; Majchrzak-Kita, B.; Lisowski, P.; Driehaus, C.; Rogalska, A.; Turner, A.; Lienhoop, T.; et al. Sirtuin 2-mediated deacetylation of cyclin-dependent kinase 9 promotes STAT1 signaling in type I interferon responses. J. Biol. Chem. 2019, 294, 827-837. [CrossRef]

97. Arslan, A.D.; Sassano, A.; Saleiro, D.; Lisowski, P.; Kosciuczuk, E.M.; Fischietti, M.; Eckerdt, F.; Fish, E.N.; Platanias, L.C. Human SLFN5 is a transcriptional co-repressor of STAT1-mediated interferon responses and promotes the malignant phenotype in glioblastoma. Oncogene 2017, 36, 6006-6019. [CrossRef]

98. Trinchieri, G. Type I interferon: Friend or foe? J. Exp. Med. 2010, 207, 2053-2063. [CrossRef] [PubMed]

99. Crow, M.K.; Olferiev, M.; Kirou, K.A. Targeting of type I interferon in systemic autoimmune diseases. Transl. Res. 2015, 165, 296-305. [CrossRef]

100. Khoo, J.J.; Forster, S.; Mansell, A. Toll-like receptors as interferon-regulated genes and their role in disease. J. Interf. Cytokine Res. 2011, 31, 13-25. [CrossRef]

101. Kumar, K.G.; Barriere, H.; Carbone, C.J.; Liu, J.; Swaminathan, G.; Xu, P.; Li, Y.; Baker, D.P.; Peng, J.; Lukacs, G.L.; et al. Site-specific ubiquitination exposes a linear motif to promote interferon-alpha receptor endocytosis. J. Cell Biol. 2007, 179, 935-950. [CrossRef]

102. Kumar, K.G.; Varghese, B.; Banerjee, A.; Baker, D.P.; Constantinescu, S.N.; Pellegrini, S.; Fuchs, S.Y. Basal ubiquitin-independent internalization of interferon alpha receptor is prevented by Tyk2-mediated masking of a linear endocytic motif. J. Biol. Chem. 2008, 283, 18566-18572. [CrossRef]

103. Liu, J.; Plotnikov, A.; Banerjee, A.; Suresh Kumar, K.G.; Ragimbeau, J.; Marijanovic, Z.; Baker, D.P.; Pellegrini, S.; Fuchs, S.Y. Ligand-independent pathway that controls stability of interferon alpha receptor. Biochem. Biophys. Res. Commun. 2008, 367, 388-393. [CrossRef]

104. Wilmes, S.; Beutel, O.; Li, Z.; Francois-Newton, V.; Richter, C.P.; Janning, D.; Kroll, C.; Hanhart, P.; Hotte, K.; You, C.; et al. Receptor dimerization dynamics as a regulatory valve for plasticity of type I interferon signaling. J. Cell Biol. 2015, 209, 579-593. [CrossRef] [PubMed]

105. Malakhova, O.A.; Kim, K.I.; Luo, J.K.; Zou, W.; Kumar, K.G.; Fuchs, S.Y.; Shuai, K.; Zhang, D.E. UBP43 is a novel regulator of interferon signaling independent of its ISG15 isopeptidase activity. EMBO J. 2006, 25, 2358-2367. [CrossRef]

106. Arimoto, K.I.; Lochte, S.; Stoner, S.A.; Burkart, C.; Zhang, Y.; Miyauchi, S.; Wilmes, S.; Fan, J.B.; Heinisch, J.J.; Li, Z.; et al. STAT2 is an essential adaptor in USP18-mediated suppression of type I interferon signaling. Nat. Struct. Mol. Biol. 2017, 24, 279-289. [CrossRef] [PubMed]

107. Francois-Newton, V.; Magno de Freitas, G.A.; Payelle-Brogard, B.; Monneron, D.; Pichard-Garcia, L.; Piehler, J.; Pellegrini, S.; Uze, G. USP18-based negative feedback control is induced by type I and type III interferons and specifically inactivates interferon alpha response. PLoS ONE 2011, 6, e22200. [CrossRef]

108. Francois-Newton, V.; Livingstone, M.; Payelle-Brogard, B.; Uze, G.; Pellegrini, S. USP18 establishes the transcriptional and anti-proliferative interferon alpha/beta differential. Biochem. J. 2012, 446, 509-516. [CrossRef]

109. Goldmann, T.; Zeller, N.; Raasch, J.; Kierdorf, K.; Frenzel, K.; Ketscher, L.; Basters, A.; Staszewski, O.; Brendecke, S.M.; Spiess, A.; et al. USP18 lack in microglia causes destructive interferonopathy of the mouse brain. EMBO J. 2015, 34, 1612-1629. [CrossRef]

110. Speer, S.D.; Li, Z.; Buta, S.; Payelle-Brogard, B.; Qian, L.; Vigant, F.; Rubino, E.; Gardner, T.J.; Wedeking, T.; Hermann, M.; et al. ISG15 deficiency and increased viral resistance in humans but not mice. Nat. Commun. 2016, 7, 11496. [CrossRef] [PubMed] 
111. Linossi, E.M.; Nicholson, S.E. Kinase inhibition, competitive binding and proteasomal degradation: Resolving the molecular function of the suppressor of cytokine signaling (SOCS) proteins. Immunol. Rev. 2015, 266, 123-133. [CrossRef]

112. Piganis, R.A.; De Weerd, N.A.; Gould, J.A.; Schindler, C.W.; Mansell, A.; Nicholson, S.E.; Hertzog, P.J. Suppressor of cytokine signaling (SOCS) 1 inhibits type I interferon (IFN) signaling via the interferon alpha receptor (IFNAR1)-associated tyrosine kinase Tyk2. J. Biol. Chem. 2011, 286, 33811-33818. [CrossRef]

113. Schoggins, J.W. Interferon-stimulated genes: What do they all do? Annu. Rev. 2019, 6, 567-584. [CrossRef] [PubMed]

114. Schoggins, J.W.; Rice, C.M. Interferon-stimulated genes and their antiviral effector functions. Curr. Opin. Virol. 2011, 1, 519-525. [CrossRef] [PubMed]

115. Hertzog, P.J.; Williams, B.R. Fine tuning type I interferon responses. Cytokine Growth Factor Rev. 2013, 24, 217-225. [CrossRef]

116. Budhwani, M.; Mazzieri, R.; Dolcetti, R. Plasticity of type I interferon-mediated responses in cancer therapy: From anti-tumor immunity to resistance. Front. Oncol. 2018, 8, 322. [CrossRef] [PubMed]

117. Platanitis, E.; Decker, T. Regulatory networks involving STATs, IRFs, and NFkappaB in inflammation. Front. Immunol. 2018, 9 , 2542. [CrossRef]

118. Josset, L.; Tchitchek, N.; Gralinski, L.E.; Ferris, M.T.; Eisfeld, A.J.; Green, R.R.; Thomas, M.J.; Tisoncik-Go, J.; Schroth, G.P.; Kawaoka, Y.; et al. Annotation of long non-coding RNAs expressed in collaborative cross founder mice in response to respiratory virus infection reveals a new class of interferon-stimulated transcripts. RNA Biol. 2014, 11, 875-890. [CrossRef] [PubMed]

119. Forster, S.C.; Tate, M.D.; Hertzog, P.J. MicroRNA as type I interferon-regulated transcripts and modulators of the innate immune response. Front. Immunol. 2015, 6, 334. [CrossRef] [PubMed]

120. Trilling, M.; Bellora, N.; Rutkowski, A.J.; de Graaf, M.; Dickinson, P.; Robertson, K.; da Costa, O.P.; Ghazal, P.; Friedel, C.C.; Alba, M.M.; et al. Deciphering the modulation of gene expression by type I and II interferons combining 4sU-tagging, translational arrest and in silico promoter analysis. Nucleic Acids Res. 2013, 41, 8107-8125. [CrossRef]

121. Megger, D.A.; Philipp, J.; Le-Trilling, V.T.K.; Sitek, B.; Trilling, M. Deciphering of the human interferon-regulated proteome by mass spectrometry-based quantitative analysis reveals extent and dynamics of protein induction and repression. Front. Immunol. 2017, 8, 1139. [CrossRef] [PubMed]

122. Crow, Y.J. Type I interferonopathies: A novel set of inborn errors of immunity. Ann. N. Y. Acad. Sci. 2011, 1238, 91-98. [CrossRef] [PubMed]

123. Jiang, J.; Zhao, M.; Chang, C.; Wu, H.; Lu, Q. Type I interferons in the pathogenesis and treatment of autoimmune diseases. Clin. Rev. Allergy Immunol. 2020, 59, 248-272. [CrossRef]

124. Ascierto, M.L.; Kmieciak, M.; Idowu, M.O.; Manjili, R.; Zhao, Y.; Grimes, M.; Dumur, C.; Wang, E.; Ramakrishnan, V.; Wang, X.Y.; et al. A signature of immune function genes associated with recurrence-free survival in breast cancer patients. Breast Cancer Res. Treat. 2012, 131, 871-880. [CrossRef]

125. Linsley, P.S.; Speake, C.; Whalen, E.; Chaussabel, D. Copy number loss of the interferon gene cluster in melanomas is linked to reduced $\mathrm{T}$ cell infiltrate and poor patient prognosis. PLoS ONE 2014, 9, e109760. [CrossRef]

126. Weichselbaum, R.R.; Ishwaran, H.; Yoon, T.; Nuyten, D.S.; Baker, S.W.; Khodarev, N.; Su, A.W.; Shaikh, A.Y.; Roach, P.; Kreike, B.; et al. An interferon-related gene signature for DNA damage resistance is a predictive marker for chemotherapy and radiation for breast cancer. Proc. Natl. Acad. Sci. USA 2008, 105, 18490-18495. [CrossRef]

127. Duarte, C.W.; Willey, C.D.; Zhi, D.; Cui, X.; Harris, J.J.; Vaughan, L.K.; Mehta, T.; McCubrey, R.O.; Khodarev, N.N.; Weichselbaum, R.R.; et al. Expression signature of IFN/STAT1 signaling genes predicts poor survival outcome in glioblastoma multiforme in a subtype-specific manner. PLoS ONE 2012, 7, e29653. [CrossRef] [PubMed]

128. Barrat, F.J.; Crow, M.K.; Ivashkiv, L.B. Interferon target-gene expression and epigenomic signatures in health and disease. Nat. Immunol. 2019, 20, 1574-1583. [CrossRef]

129. Smale, S.T.; Tarakhovsky, A.; Natoli, G. Chromatin contributions to the regulation of innate immunity. Annu. Rev. Immunol. 2014, 32, 489-511. [CrossRef] [PubMed]

130. Ostuni, R.; Piccolo, V.; Barozzi, I.; Polletti, S.; Termanini, A.; Bonifacio, S.; Curina, A.; Prosperini, E.; Ghisletti, S.; Natoli, G. Latent enhancers activated by stimulation in differentiated cells. Cell 2013, 152, 157-171. [CrossRef]

131. Kamada, R.; Yang, W.; Zhang, Y.; Patel, M.C.; Yang, Y.; Ouda, R.; Dey, A.; Wakabayashi, Y.; Sakaguchi, K.; Fujita, T.; et al. Interferon stimulation creates chromatin marks and establishes transcriptional memory. Proc. Natl. Acad. Sci. USA 2018, 115, E9162-E9171. [CrossRef]

132. Park, S.H.; Kang, K.; Giannopoulou, E.; Qiao, Y.; Kang, K.; Kim, G.; Park-Min, K.H.; Ivashkiv, L.B. Type I interferons and the cytokine TNF cooperatively reprogram the macrophage epigenome to promote inflammatory activation. Nat. Immunol. 2017, 18, 1104-1116. [CrossRef]

133. Netea, M.G.; Joosten, L.A.; Latz, E.; Mills, K.H.; Natoli, G.; Stunnenberg, H.G.; O’Neill, L.A.; Xavier, R.J. Trained immunity: A program of innate immune memory in health and disease. Science 2016, 352, aaf1098. [CrossRef] [PubMed]

134. Monticelli, S.; Natoli, G. Short-term memory of danger signals and environmental stimuli in immune cells. Nat. Immunol. 2013, 14, 777-784. [CrossRef]

135. Zitvogel, L.; Galluzzi, L.; Kepp, O.; Smyth, M.J.; Kroemer, G. Type I interferons in anticancer immunity. Nat. Rev. Immunol. 2015, 15, 405-414. [CrossRef] [PubMed] 
136. Manic, G.; Musella, M.; Corradi, F.; Sistigu, A.; Vitale, S.; Abdel Rehim, S.S.; Mattiello, L.; Malacaria, E.; Galassi, C.; Signore, M.; et al. Control of replication stress and mitosis in colorectal cancer stem cells through the interplay of PARP1, MRE11 and RAD51. Cell Death Differ. 2021, 28, 2060-2082. [CrossRef] [PubMed]

137. Di Franco, S.; Turdo, A.; Todaro, M.; Stassi, G. Role of type I and II interferons in colorectal cancer and melanoma. Front. Immunol. 2017, 8, 878. [CrossRef]

138. Hobeika, A.C.; Subramaniam, P.S.; Johnson, H.M. IFNalpha induces the expression of the cyclin-dependent kinase inhibitor p21 in human prostate cancer cells. Oncogene 1997, 14, 1165-1170. [CrossRef]

139. Balkwill, F.; Watling, D.; Taylor-Papadimitriou, J. Inhibition by lymphoblastoid interferon of growth of cells derived from the human breast. Int. J. Cancer 1978, 22, 258-265. [CrossRef]

140. Sangfelt, O.; Erickson, S.; Grander, D. Mechanisms of interferon-induced cell cycle arrest. Front. Biosci. 2000, 5, D479-D487. [CrossRef]

141. Matsuoka, M.; Tani, K.; Asano, S. Interferon-alpha-induced G1 phase arrest through up-regulated expression of CDK inhibitors, p19Ink4D and p21Cip1 in mouse macrophages. Oncogene 1998, 16, 2075-2086. [CrossRef]

142. Katayama, T.; Nakanishi, K.; Nishihara, H.; Kamiyama, N.; Nakagawa, T.; Kamiyama, T.; Iseki, K.; Tanaka, S.; Todo, S. Type I interferon prolongs cell cycle progression via p21WAF1/CIP1 induction in human colon cancer cells. Int. J. Oncol. 2007, 31, 613-620. [CrossRef]

143. Lu, M.; Zhang, W.; Li, Y.; Berenzon, D.; Wang, X.; Wang, J.; Mascarenhas, J.; Xu, M.; Hoffman, R. Interferon-alpha targets JAK2V617F-positive hematopoietic progenitor cells and acts through the p38 MAPK pathway. Exp. Hematol. 2010, 38, 472-480. [CrossRef]

144. Platanias, L.C.; Uddin, S.; Bruno, E.; Korkmaz, M.; Ahmad, S.; Alsayed, Y.; Van Den Berg, D.; Druker, B.J.; Wickrema, A.; Hoffman, R. CrkL and CrkII participate in the generation of the growth inhibitory effects of interferons on primary hematopoietic progenitors. Exp. Hematol. 1999, 27, 1315-1321. [CrossRef]

145. Thyrell, L.; Erickson, S.; Zhivotovsky, B.; Pokrovskaja, K.; Sangfelt, O.; Castro, J.; Einhorn, S.; Grander, D. Mechanisms of interferon-alpha induced apoptosis in malignant cells. Oncogene 2002, 21, 1251-1262. [CrossRef] [PubMed]

146. Choi, E.A.; Lei, H.; Maron, D.J.; Wilson, J.M.; Barsoum, J.; Fraker, D.L.; El-Deiry, W.S.; Spitz, F.R. Stat1-dependent induction of tumor necrosis factor-related apoptosis-inducing ligand and the cell-surface death signaling pathway by interferon beta in human cancer cells. Cancer Res. 2003, 63, 5299-5307. [PubMed]

147. Bernardo, A.R.; Cosgaya, J.M.; Aranda, A.; Jimenez-Lara, A.M. Synergy between RA and TLR3 promotes type I IFN-dependent apoptosis through upregulation of TRAIL pathway in breast cancer cells. Cell Death Dis. 2013, 4, e479. [CrossRef]

148. Chawla-Sarkar, M.; Lindner, D.J.; Liu, Y.F.; Williams, B.R.; Sen, G.C.; Silverman, R.H.; Borden, E.C. Apoptosis and interferons: Role of interferon-stimulated genes as mediators of apoptosis. Apoptosis 2003, 8, 237-249. [CrossRef] [PubMed]

149. Frank, T.; Tuppi, M.; Hugle, M.; Dotsch, V.; van Wijk, S.J.L.; Fulda, S. Cell cycle arrest in mitosis promotes interferon-induced necroptosis. Cell Death Differ. 2019, 26, 2046-2060. [CrossRef] [PubMed]

150. Katlinskaya, Y.V.; Katlinski, K.V.; Yu, Q.; Ortiz, A.; Beiting, D.P.; Brice, A.; Davar, D.; Sanders, C.; Kirkwood, J.M.; Rui, H.; et al. Suppression of type I interferon signaling overcomes oncogene-induced senescence and mediates melanoma development and progression. Cell Rep. 2016, 15, 171-180. [CrossRef]

151. Yang, H.; Wang, H.; Ren, J.; Chen, Q.; Chen, Z.J. cGAS is essential for cellular senescence. Proc. Natl. Acad. Sci. USA 2017, 114, E4612-E4620. [CrossRef] [PubMed]

152. Gluck, S.; Ablasser, A. Innate immunosensing of DNA in cellular senescence. Curr. Opin. Immunol. 2019, 56, 31-36. [CrossRef] [PubMed]

153. Gresser, I.; Maury, C.; Brouty-Boye, D. Mechanism of the antitumour effect of interferon in mice. Nature 1972, $239,167-168$. [CrossRef]

154. Chen, D.S.; Mellman, I. Oncology meets immunology: The cancer-immunity cycle. Immunity 2013, 39, 1-10. [CrossRef]

155. Ferrantini, M.; Proietti, E.; Santodonato, L.; Gabriele, L.; Peretti, M.; Plavec, I.; Meyer, F.; Kaido, T.; Gresser, I.; Belardelli, F. Alpha 1-interferon gene transfer into metastatic friend leukemia cells abrogated tumorigenicity in immunocompetent mice: Antitumor therapy by means of interferon-producing cells. Cancer Res. 1993, 53, 1107-1112.

156. Ferrantini, M.; Giovarelli, M.; Modesti, A.; Musiani, P.; Modica, A.; Venditti, M.; Peretti, E.; Lollini, P.L.; Nanni, P.; Forni, G.; et al. IFN-alpha 1 gene expression into a metastatic murine adenocarcinoma (TS/A) results in CD8+ T cell-mediated tumor rejection and development of antitumor immunity. Comparative studies with IFN-gamma-producing TS/A cells. J. Immunol. 1994, 153, 4604-4615. [PubMed]

157. Dunn, G.P.; Sheehan, K.C.; Old, L.J.; Schreiber, R.D. IFN unresponsiveness in LNCaP cells due to the lack of JAK1 gene expression. Cancer Res. 2005, 65, 3447-3453. [CrossRef]

158. Schreiber, R.D.; Old, L.J.; Smyth, M.J. Cancer immunoediting: Integrating immunity's roles in cancer suppression and promotion. Science 2011, 331, 1565-1570. [CrossRef]

159. Boyer, C.M.; Dawson, D.V.; Neal, S.E.; Winchell, L.F.; Leslie, D.S.; Ring, D.; Bast, R.C.J. Differential induction by interferons of major histocompatibility complex-encoded and non-major histocompatibility complex-encoded antigens in human breast and ovarian carcinoma cell lines. Cancer Res. 1989, 49, 2928-2934. 
160. Greiner, J.W.; Hand, P.H.; Noguchi, P.; Fisher, P.B.; Pestka, S.; Schlom, J. Enhanced expression of surface tumor-associated antigens on human breast and colon tumor cells after recombinant human leukocyte alpha-interferon treatment. Cancer Res. 1984, 44, 3208-3214.

161. Giacomini, P.; Fraioli, R.; Nistico, P.; Tecce, R.; Nicotra, M.R.; Di Filippo, F.; Fisher, P.B.; Natali, P.G. Modulation of the antigenic phenotype of early-passage human melanoma cells derived from multiple autologous metastases by recombinant human leukocyte, fibroblast and immune interferon. Int. J. Cancer 1990, 46, 539-545. [CrossRef]

162. Dunn, I.S.; Haggerty, T.J.; Kono, M.; Durda, P.J.; Butera, D.; Macdonald, D.B.; Benson, E.M.; Rose, L.B.; Kurnick, J.T. Enhancement of human melanoma antigen expression by IFN-beta. J. Immunol. 2007, 179, 2134-2142. [CrossRef]

163. Dolei, A.; Capobianchi, M.R.; Ameglio, F. Human interferon-gamma enhances the expression of class I and class II major histocompatibility complex products in neoplastic cells more effectively than interferon-alpha and interferon-beta. Infect. Immun. 1983, 40, 172-176. [CrossRef] [PubMed]

164. Lanza, L.; Peirano, L.; Bosco, O.; Contini, P.; Filaci, G.; Setti, M.; Puppo, F.; Indiveri, F.; Scudeletti, M. Interferons up-regulate with different potency HLA class I antigen expression in M14 human melanoma cell line. Possible interaction with glucocorticoid hormones. Cancer Immunol. Immunother. 1995, 41, 23-28. [CrossRef] [PubMed]

165. Nassar, D.; Blanpain, C. Cancer stem cells: Basic concepts and therapeutic implications. Annu. Rev. Pathol. 2016, 11, 47-76. [CrossRef] [PubMed]

166. Prager, B.C.; Xie, Q.; Bao, S.; Rich, J.N. Cancer stem cells: The architects of the tumor ecosystem. Cell Stem Cell 2019, $24,41-53$. [CrossRef]

167. Castiello, L.; Sestili, P.; Schiavoni, G.; Dattilo, R.; Monque, D.M.; Ciaffoni, F.; Iezzi, M.; Lamolinara, A.; Sistigu, A.; Moschella, F.; et al. Disruption of IFN-I signaling promotes HER2/Neu tumor progression and breast cancer stem cells. Cancer Immunol. Res. 2018, 6, 658-670. [CrossRef]

168. Doherty, M.R.; Cheon, H.; Junk, D.J.; Vinayak, S.; Varadan, V.; Telli, M.L.; Ford, J.M.; Stark, G.R.; Jackson, M.W. Interferon-beta represses cancer stem cell properties in triple-negative breast cancer. Proc. Natl. Acad. Sci. USA 2017, 114, 13792-13797. [CrossRef]

169. Yuki, K.; Natsume, A.; Yokoyama, H.; Kondo, Y.; Ohno, M.; Kato, T.; Chansakul, P.; Ito, M.; Kim, S.U.; Wakabayashi, T. Induction of oligodendrogenesis in glioblastoma-initiating cells by IFN-mediated activation of STAT3 signaling. Cancer Lett. 2009, 284, 71-79. [CrossRef]

170. Du, Z.; Cai, C.; Sims, M.; Boop, F.A.; Davidoff, A.M.; Pfeffer, L.M. The effects of type I interferon on glioblastoma cancer stem cells. Biochem. Biophys. Res. Commun. 2017, 491, 343-348. [CrossRef] [PubMed]

171. Zhan, X.; Guo, S.; Li, Y.; Ran, H.; Huang, H.; Mi, L.; Wu, J.; Wang, X.; Xiao, D.; Chen, L.; et al. Glioma stem-like cells evade interferon suppression through MBD3/NuRD complex-mediated STAT1 downregulation. J. Exp. Med. 2020, 217. [CrossRef] [PubMed]

172. Shimoda, M.; Ota, M.; Okada, Y. Isolation of cancer stem cells by side population method. Methods Mol. Biol. 2018, 1692, 49-59. [CrossRef]

173. Liang, Y.; Hannan, R.; Fu, Y.X. Type I IFN activating type I dendritic cells for antitumor immunity. Clin. Cancer Res. 2021, 27, 3818-3824. [CrossRef]

174. Lorenzi, S.; Mattei, F.; Sistigu, A.; Bracci, L.; Spadaro, F.; Sanchez, M.; Spada, M.; Belardelli, F.; Gabriele, L.; Schiavoni, G. Type I IFNs control antigen retention and survival of CD8alpha(+) dendritic cells after uptake of tumor apoptotic cells leading to cross-priming. J. Immunol. 2011, 186, 5142-5150. [CrossRef] [PubMed]

175. Diamond, M.S.; Kinder, M.; Matsushita, H.; Mashayekhi, M.; Dunn, G.P.; Archambault, J.M.; Lee, H.; Arthur, C.D.; White, J.M.; Kalinke, U.; et al. Type I interferon is selectively required by dendritic cells for immune rejection of tumors. J. Exp. Med. 2011, 208, 1989-2003. [CrossRef] [PubMed]

176. Curtsinger, J.M.; Valenzuela, J.O.; Agarwal, P.; Lins, D.; Mescher, M.F. Type I IFNs provide a third signal to CD8 T cells to stimulate clonal expansion and differentiation. J. Immunol. 2005, 174, 4465-4469. [CrossRef]

177. Tough, D.F. Modulation of T-cell function by type I interferon. Immunol. Cell Biol. 2012, 90, 492-497. [CrossRef]

178. Crouse, J.; Kalinke, U.; Oxenius, A. Regulation of antiviral T cell responses by type I interferons. Nat. Rev. Immunol. 2015, 15, 231-242. [CrossRef]

179. Lim, J.Y.; Gerber, S.A.; Murphy, S.P.; Lord, E.M. Type I interferons induced by radiation therapy mediate recruitment and effector function of CD8(+) T cells. Cancer Immunol. Immunother. 2014, 63, 259-271. [CrossRef] [PubMed]

180. Medrano, R.F.V.; Hunger, A.; Mendonca, S.A.; Barbuto, J.A.M.; Strauss, B.E. Immunomodulatory and antitumor effects of type I interferons and their application in cancer therapy. Oncotarget 2017, 8, 71249-71284. [CrossRef]

181. Le Bon, A.; Durand, V.; Kamphuis, E.; Thompson, C.; Bulfone-Paus, S.; Rossmann, C.; Kalinke, U.; Tough, D.F. Direct stimulation of T cells by type I IFN enhances the CD8+ T cell response during cross-priming. J. Immunol. 2006, 176, 4682-4689. [CrossRef]

182. Richer, M.J.; Nolz, J.C.; Harty, J.T. Pathogen-specific inflammatory milieux tune the antigen sensitivity of CD8(+) T cells by enhancing T cell receptor signaling. Immunity 2013, 38, 140-152. [CrossRef] [PubMed]

183. Lu, C.; Klement, J.D.; Ibrahim, M.L.; Xiao, W.; Redd, P.S.; Nayak-Kapoor, A.; Zhou, G.; Liu, K. Type I interferon suppresses tumor growth through activating the STAT3-granzyme B pathway in tumor-infiltrating cytotoxic T lymphocytes. J. Immunother. Cancer 2019, 7, 157. [CrossRef] [PubMed]

184. Im, S.J.; Hashimoto, M.; Gerner, M.Y.; Lee, J.; Kissick, H.T.; Burger, M.C.; Shan, Q.; Hale, J.S.; Lee, J.; Nasti, T.H.; et al. Defining CD8+ T cells that provide the proliferative burst after PD-1 therapy. Nature 2016, 537, 417-421. [CrossRef] 
185. Siddiqui, I.; Schaeuble, K.; Chennupati, V.; Fuertes Marraco, S.A.; Calderon-Copete, S.; Pais Ferreira, D.; Carmona, S.J.; Scarpellino, L.; Gfeller, D.; Pradervand, S.; et al. Intratumoral Tcf1(+)PD-1(+)CD8(+) T cells with stem-like properties promote tumor control in response to vaccination and checkpoint blockade immunotherapy. Immunity 2019, 50, 195-211.e110. [CrossRef]

186. Snell, L.M.; MacLeod, B.L.; Law, J.C.; Osokine, I.; Elsaesser, H.J.; Hezaveh, K.; Dickson, R.J.; Gavin, M.A.; Guidos, C.J.; McGaha, T.L.; et al. CD8(+) T cell priming in established chronic viral infection preferentially directs differentiation of memory-like cells for sustained immunity. Immunity 2018, 49, 678-694.e675. [CrossRef] [PubMed]

187. Miron, M.; Kumar, B.V.; Meng, W.; Granot, T.; Carpenter, D.J.; Senda, T.; Chen, D.; Rosenfeld, A.M.; Zhang, B.; Lerner, H.; et al. Human lymph nodes maintain TCF-1(hi) memory T cells with high functional potential and clonal diversity throughout life. J. Immunol. 2018, 201, 2132-2140. [CrossRef]

188. Huber, J.P.; Farrar, J.D. Regulation of effector and memory T-cell functions by type I interferon. Immunology 2011, 132, 466-474. [CrossRef]

189. Szabo, S.J.; Kim, S.T.; Costa, G.L.; Zhang, X.; Fathman, C.G.; Glimcher, L.H. A novel transcription factor, T-bet, directs Th1 lineage commitment. Cell 2000, 100, 655-669. [CrossRef]

190. Hashimoto, H.; Ueda, R.; Narumi, K.; Heike, Y.; Yoshida, T.; Aoki, K. Type I IFN gene delivery suppresses regulatory T cells within tumors. Cancer Gene Ther. 2014, 21, 532-541. [CrossRef]

191. Hirata, A.; Hashimoto, H.; Shibasaki, C.; Narumi, K.; Aoki, K. Intratumoral IFN-alpha gene delivery reduces tumor-infiltrating regulatory T cells through the downregulation of tumor CCL17 expression. Cancer Gene Ther. 2019, 26, 334-343. [CrossRef]

192. Pace, L.; Vitale, S.; Dettori, B.; Palombi, C.; La Sorsa, V.; Belardelli, F.; Proietti, E.; Doria, G. APC activation by IFN-alpha decreases regulatory $\mathrm{T}$ cell and enhances Th cell functions. J. Immunol. 2010, 184, 5969-5979. [CrossRef]

193. Mizutani, T.; Neugebauer, N.; Putz, E.M.; Moritz, N.; Simma, O.; Zebedin-Brandl, E.; Gotthardt, D.; Warsch, W.; Eckelhart, E.; Kantner, H.P.; et al. Conditional IFNAR1 ablation reveals distinct requirements of type I IFN signaling for NK cell maturation and tumor surveillance. Oncoimmunology 2012, 1, 1027-1037. [CrossRef]

194. Rautela, J.; Baschuk, N.; Slaney, C.Y.; Jayatilleke, K.M.; Xiao, K.; Bidwell, B.N.; Lucas, E.C.; Hawkins, E.D.; Lock, P.; Wong, C.S.; et al. Loss of host type-I IFN signaling accelerates metastasis and impairs NK-cell antitumor function in multiple models of breast cancer. Cancer Immunol. Res. 2015, 3, 1207-1217. [CrossRef]

195. Zanker, D.J.; Owen, K.L.; Baschuk, N.; Spurling, A.J.; Parker, B.S. Loss of type I IFN responsiveness impairs natural killer cell antitumor activity in breast cancer. Cancer Immunol. Immunother. 2021, 70, 2125-2138. [CrossRef] [PubMed]

196. Parker, B.S.; Rautela, J.; Hertzog, P.J. Antitumour actions of interferons: Implications for cancer therapy. Nat. Rev. Cancer 2016, 16, 131-144. [CrossRef]

197. Zoglmeier, C.; Bauer, H.; Noerenberg, D.; Wedekind, G.; Bittner, P.; Sandholzer, N.; Rapp, M.; Anz, D.; Endres, S.; Bourquin, C. CpG blocks immunosuppression by myeloid-derived suppressor cells in tumor-bearing mice. Clin. Cancer Res. 2011, 17, 1765-1775. [CrossRef]

198. Muller, E.; Speth, M.; Christopoulos, P.F.; Lunde, A.; Avdagic, A.; Oynebraten, I.; Corthay, A. Both type I and type II interferons can activate antitumor M1 macrophages when combined with TLR stimulation. Front. Immunol. 2018, 9, 2520. [CrossRef] [PubMed]

199. Nardelli, B.; Zaritskaya, L.; Semenuk, M.; Cho, Y.H.; LaFleur, D.W.; Shah, D.; Ullrich, S.; Girolomoni, G.; Albanesi, C.; Moore, P.A. Regulatory effect of IFN-kappa, a novel type I IFN, on cytokine production by cells of the innate immune system. J. Immunol. 2002, 169, 4822-4830. [CrossRef] [PubMed]

200. Andzinski, L.; Kasnitz, N.; Stahnke, S.; Wu, C.F.; Gereke, M.; von Kockritz-Blickwede, M.; Schilling, B.; Brandau, S.; Weiss, S.; Jablonska, J. Type I IFNs induce anti-tumor polarization of tumor associated neutrophils in mice and human. Int. J. Cancer 2016, 138, 1982-1993. [CrossRef]

201. Liu, Y.; Ma, J.; Yang, Y.; Liu, L.; Zhu, G.; Wang, X.; Wang, S.; Guo, W.; Yue, Q.; Zhao, T.; et al. Impact of interferon-alpha1b (IFN-alpha1b) on antitumor immune response: An interpretation of the promising therapeutic effect of IFN-alpha1b on melanoma. Med Sci. Monit. 2020, 26, e922790. [CrossRef]

202. Villanueva, A.I.; Haeryfar, S.M.; Mallard, B.A.; Kulkarni, R.R.; Sharif, S. Functions of invariant NK T cells are modulated by TLR ligands and IFN-alpha. Innate Immun. 2015, 21, 275-288. [CrossRef]

203. Watanabe, N.; Narita, M.; Yokoyama, A.; Sekiguchi, A.; Saito, A.; Tochiki, N.; Furukawa, T.; Toba, K.; Aizawa, Y.; Takahashi, M. Type I IFN-mediated enhancement of anti-leukemic cytotoxicity of gammadelta T cells expanded from peripheral blood cells by stimulation with zoledronate. Cytotherapy 2006, 8, 118-129. [CrossRef] [PubMed]

204. Le Bon, A.; Thompson, C.; Kamphuis, E.; Durand, V.; Rossmann, C.; Kalinke, U.; Tough, D.F. Cutting edge: Enhancement of antibody responses through direct stimulation of B and T cells by type I IFN. J. Immunol. 2006, 176, 2074-2078. [CrossRef] [PubMed]

205. Swanson, C.L.; Wilson, T.J.; Strauch, P.; Colonna, M.; Pelanda, R.; Torres, R.M. Type I IFN enhances follicular B cell contribution to the T cell-independent antibody response. J. Exp. Med. 2010, 207, 1485-1500. [CrossRef] [PubMed]

206. Boukhaled, G.M.; Harding, S.; Brooks, D.G. Opposing roles of type I interferons in cancer immunity. Annu. Rev. Pathol. 2021, 16, 167-198. [CrossRef] [PubMed]

207. Indraccolo, S. Interferon-alpha as angiogenesis inhibitor: Learning from tumor models. Autoimmunity 2010, 43, $244-247$. [CrossRef] 
208. Yang, H.; Lee, W.S.; Kong, S.J.; Kim, C.G.; Kim, J.H.; Chang, S.K.; Kim, S.; Kim, G.; Chon, H.J.; Kim, C. STING activation reprograms tumor vasculatures and synergizes with VEGFR2 blockade. J. Clin. Investig. 2019, 129, 4350-4364. [CrossRef] [PubMed]

209. Wu, D.; Sanin, D.E.; Everts, B.; Chen, Q.; Qiu, J.; Buck, M.D.; Patterson, A.; Smith, A.M.; Chang, C.H.; Liu, Z.; et al. Type 1 interferons induce changes in core metabolism that are critical for immune function. Immunity 2016, 44, 1325-1336. [CrossRef]

210. Pantel, A.; Teixeira, A.; Haddad, E.; Wood, E.G.; Steinman, R.M.; Longhi, M.P. Direct type I IFN but not MDA5/TLR3 activation of dendritic cells is required for maturation and metabolic shift to glycolysis after poly IC stimulation. PLoS Biol. 2014, 12, e1001759. [CrossRef]

211. York, A.G.; Williams, K.J.; Argus, J.P.; Zhou, Q.D.; Brar, G.; Vergnes, L.; Gray, E.E.; Zhen, A.; Wu, N.C.; Yamada, D.H.; et al. Limiting cholesterol biosynthetic flux spontaneously engages type I IFN signaling. Cell 2015, 163, 1716-1729. [CrossRef]

212. Pfeffer, L.M. The role of nuclear factor kappaB in the interferon response. J. Interf. Cytokine Res. 2011, 31, 553-559. [CrossRef]

213. Yang, C.H.; Murti, A.; Pfeffer, S.R.; Basu, L.; Kim, J.G.; Pfeffer, L.M. IFNalpha/beta promotes cell survival by activating NF-kappa B. Proc. Natl. Acad. Sci. USA 2000, 97, 13631-13636. [CrossRef]

214. Cheriyath, V.; Kuhns, M.A.; Jacobs, B.S.; Evangelista, P.; Elson, P.; Downs-Kelly, E.; Tubbs, R.; Borden, E.C. G1P3, an interferonand estrogen-induced survival protein contributes to hyperplasia, tamoxifen resistance and poor outcomes in breast cancer. Oncogene 2012, 31, 2222-2236. [CrossRef]

215. Puthier, D.; Thabard, W.; Rapp, M.; Etrillard, M.; Harousseau, J.; Bataille, R.; Amiot, M. Interferon alpha extends the survival of human myeloma cells through an upregulation of the Mcl-1 anti-apoptotic molecule. Br. J. Haematol. 2001, 112, 358-363. [CrossRef] [PubMed]

216. Hatano, H.; Kudo, Y.; Ogawa, I.; Tsunematsu, T.; Kikuchi, A.; Abiko, Y.; Takata, T. IFN-induced transmembrane protein 1 promotes invasion at early stage of head and neck cancer progression. Clin. Cancer Res. 2008, 14, 6097-6105. [CrossRef] [PubMed]

217. Yan, J.; Jiang, Y.; Lu, J.; Wu, J.; Zhang, M. Inhibiting of proliferation, migration, and invasion in lung cancer induced by silencing interferon-induced transmembrane protein 1 (IFITM1). BioMed Res. Int. 2019, 2019, 9085435. [CrossRef]

218. Zitvogel, L.; Tesniere, A.; Kroemer, G. Cancer despite immunosurveillance: Immunoselection and immunosubversion. Nat. Rev. Immunol. 2006, 6, 715-727. [CrossRef] [PubMed]

219. Chen, W.; Liang, X.; Peterson, A.J.; Munn, D.H.; Blazar, B.R. The indoleamine 2,3-dioxygenase pathway is essential for human plasmacytoid dendritic cell-induced adaptive T regulatory cell generation. J. Immunol. 2008, 181, 5396-5404. [CrossRef]

220. Cunningham, C.R.; Champhekar, A.; Tullius, M.V.; Dillon, B.J.; Zhen, A.; de la Fuente, J.R.; Herskovitz, J.; Elsaesser, H.; Snell, L.M.; Wilson, E.B.; et al. Type I and type II interferon coordinately regulate suppressive dendritic cell fate and function during viral persistence. PLoS Pathog. 2016, 12, e1005356. [CrossRef] [PubMed]

221. Pallotta, M.T.; Orabona, C.; Volpi, C.; Vacca, C.; Belladonna, M.L.; Bianchi, R.; Servillo, G.; Brunacci, C.; Calvitti, M.; Bicciato, S.; et al. Indoleamine 2,3-dioxygenase is a signaling protein in long-term tolerance by dendritic cells. Nat. Immunol. 2011, 12, 870-878. [CrossRef]

222. Baban, B.; Chandler, P.R.; Sharma, M.D.; Pihkala, J.; Koni, P.A.; Munn, D.H.; Mellor, A.L. IDO activates regulatory T cells and blocks their conversion into Th17-like T cells. J. Immunol. 2009, 183, 2475-2483. [CrossRef] [PubMed]

223. Fallarino, F.; Grohmann, U.; You, S.; McGrath, B.C.; Cavener, D.R.; Vacca, C.; Orabona, C.; Bianchi, R.; Belladonna, M.L.; Volpi, C.; et al. The combined effects of tryptophan starvation and tryptophan catabolites down-regulate $\mathrm{T}$ cell receptor zeta-chain and induce a regulatory phenotype in naive T cells. J. Immunol. 2006, 176, 6752-6761. [CrossRef] [PubMed]

224. Coppe, J.P.; Desprez, P.Y.; Krtolica, A.; Campisi, J. The senescence-associated secretory phenotype: The dark side of tumor suppression. Annu. Rev. Pathol. 2010, 5, 99-118. [CrossRef] [PubMed]

225. Kumari, N.; Dwarakanath, B.S.; Das, A.; Bhatt, A.N. Role of interleukin-6 in cancer progression and therapeutic resistance. Tumour Biol. 2016, 37, 11553-11572. [CrossRef] [PubMed]

226. Benci, J.L.; Johnson, L.R.; Choa, R.; Xu, Y.; Qiu, J.; Zhou, Z.; Xu, B.; Ye, D.; Nathanson, K.L.; June, C.H.; et al. Opposing functions of interferon coordinate adaptive and innate immune responses to cancer immune checkpoint blockade. Cell 2019, 178, 933-948.e914. [CrossRef]

227. Benci, J.L.; Xu, B.; Qiu, Y.; Wu, T.J.; Dada, H.; Twyman-Saint Victor, C.; Cucolo, L.; Lee, D.S.M.; Pauken, K.E.; Huang, A.C.; et al. Tumor interferon signaling regulates a multigenic resistance program to immune checkpoint blockade. Cell 2016, 167, 1540-1554.e1512. [CrossRef]

228. Bald, T.; Landsberg, J.; Lopez-Ramos, D.; Renn, M.; Glodde, N.; Jansen, P.; Gaffal, E.; Steitz, J.; Tolba, R.; Kalinke, U.; et al. Immune cell-poor melanomas benefit from PD-1 blockade after targeted type I IFN activation. Cancer Discov. 2014, 4, 674-687. [CrossRef]

229. Jacquelot, N.; Yamazaki, T.; Roberti, M.P.; Duong, C.P.M.; Andrews, M.C.; Verlingue, L.; Ferrere, G.; Becharef, S.; Vetizou, M.; Daillere, R.; et al. Sustained type I interferon signaling as a mechanism of resistance to PD-1 blockade. Cell Res. $2019,29,846-861$. [CrossRef]

230. Kitamura, T.; Qian, B.Z.; Pollard, J.W. Immune cell promotion of metastasis. Nat. Rev. Immunol. 2015, 15, 73-86. [CrossRef]

231. Li, S.; Xie, Y.; Zhang, W.; Gao, J.; Wang, M.; Zheng, G.; Yin, X.; Xia, H.; Tao, X. Interferon alpha-inducible protein 27 promotes epithelial-mesenchymal transition and induces ovarian tumorigenicity and stemness. J. Surg. Res. 2015, 193, 255-264. [CrossRef]

232. Ma, H.; Jin, S.; Yang, W.; Tian, Z.; Liu, S.; Wang, Y.; Zhou, G.; Zhao, M.; Gvetadze, S.; Zhang, Z.; et al. Interferon-alpha promotes the expression of cancer stem cell markers in oral squamous cell carcinoma. J. Cancer 2017, 8, 2384-2393. [CrossRef] [PubMed] 
233. Zhu, Y.; Karakhanova, S.; Huang, X.; Deng, S.P.; Werner, J.; Bazhin, A.V. Influence of interferon-alpha on the expression of the cancer stem cell markers in pancreatic carcinoma cells. Exp. Cell Res. 2014, 324, 146-156. [CrossRef]

234. Sainz, B., Jr.; Martin, B.; Tatari, M.; Heeschen, C.; Guerra, S. ISG15 is a critical microenvironmental factor for pancreatic cancer stem cells. Cancer Res. 2014, 74, 7309-7320. [CrossRef] [PubMed]

235. Qadir, A.S.; Ceppi, P.; Brockway, S.; Law, C.; Mu, L.; Khodarev, N.N.; Kim, J.; Zhao, J.C.; Putzbach, W.; Murmann, A.E.; et al. CD95/Fas increases stemness in cancer cells by inducing a STAT1-dependent type I interferon response. Cell Rep. 2017, 18, 2373-2386. [CrossRef] [PubMed]

236. Meng, S.; Chanda, P.; Thandavarayan, R.A.; Cooke, J.P. Transflammation: Innate immune signaling in nuclear reprogramming. Adv. Drug Deliv. Rev. 2017, 120, 133-141. [CrossRef] [PubMed]

237. Lee, J.; Sayed, N.; Hunter, A.; Au, K.F.; Wong, W.H.; Mocarski, E.S.; Pera, R.R.; Yakubov, E.; Cooke, J.P. Activation of innate immunity is required for efficient nuclear reprogramming. Cell 2012, 151, 547-558. [CrossRef]

238. Sayed, N.; Ospino, F.; Himmati, F.; Lee, J.; Chanda, P.; Mocarski, E.S.; Cooke, J.P. Retinoic acid inducible gene 1 protein (RIG1)-like receptor pathway is required for efficient nuclear reprogramming. Stem Cells 2017, 35, 1197-1207. [CrossRef]

239. Jia, D.; Yang, W.; Li, L.; Liu, H.; Tan, Y.; Ooi, S.; Chi, L.; Filion, L.G.; Figeys, D.; Wang, L. Beta-Catenin and NF-kappaB co-activation triggered by TLR3 stimulation facilitates stem cell-like phenotypes in breast cancer. Cell Death Differ. 2015, 22, 298-310. [CrossRef]

240. Lan, Q.; Peyvandi, S.; Duffey, N.; Huang, Y.T.; Barras, D.; Held, W.; Richard, F.; Delorenzi, M.; Sotiriou, C.; Desmedt, C.; et al. Type I interferon/IRF7 axis instigates chemotherapy-induced immunological dormancy in breast cancer. Oncogene 2019, 38, $2814-2829$. [CrossRef]

241. Sistigu, A.; Musella, M.; Galassi, C.; Vitale, I.; De Maria, R. Tuning cancer fate: Tumor microenvironment's role in cancer stem cell quiescence and reawakening. Front. Immunol. 2020, 11, 2166. [CrossRef]

242. Fucikova, J.; Kepp, O.; Kasikova, L.; Petroni, G.; Yamazaki, T.; Liu, P.; Zhao, L.; Spisek, R.; Kroemer, G.; Galluzzi, L. Detection of immunogenic cell death and its relevance for cancer therapy. Cell Death Dis. 2020, 11, 1013. [CrossRef] [PubMed]

243. Schiavoni, G.; Sistigu, A.; Valentini, M.; Mattei, F.; Sestili, P.; Spadaro, F.; Sanchez, M.; Lorenzi, S.; D’Urso, M.T.; Belardelli, F.; et al. Cyclophosphamide synergizes with type I interferons through systemic dendritic cell reactivation and induction of immunogenic tumor apoptosis. Cancer Res. 2011, 71, 768-778. [CrossRef] [PubMed]

244. Zitvogel, L.; Pitt, J.M.; Daillere, R.; Smyth, M.J.; Kroemer, G. Mouse models in oncoimmunology. Nat. Rev. Cancer 2016, 16, 759-773. [CrossRef]

245. Swann, J.B.; Vesely, M.D.; Silva, A.; Sharkey, J.; Akira, S.; Schreiber, R.D.; Smyth, M.J. Demonstration of inflammation-induced cancer and cancer immunoediting during primary tumorigenesis. Proc. Natl. Acad. Sci. USA 2008, 105, 652-656. [CrossRef]

246. Heyer, J.; Kwong, L.N.; Lowe, S.W.; Chin, L. Non-germline genetically engineered mouse models for translational cancer research. Nat. Rev. Cancer 2010, 10, 470-480. [CrossRef]

247. Walsh, N.C.; Kenney, L.L.; Jangalwe, S.; Aryee, K.E.; Greiner, D.L.; Brehm, M.A.; Shultz, L.D. Humanized mouse models of clinical disease. Annu. Rev. Pathol. 2017, 12, 187-215. [CrossRef] [PubMed]

248. Dunn, G.P.; Koebel, C.M.; Schreiber, R.D. Interferons, immunity and cancer immunoediting. Nat. Rev. Immunol. 2006, 6, 836-848. [CrossRef]

249. Galluzzi, L.; Vitale, I.; Warren, S.; Adjemian, S.; Agostinis, P.; Martinez, A.B.; Chan, T.A.; Coukos, G.; Demaria, S.; Deutsch, E.; et al. Consensus guidelines for the definition, detection and interpretation of immunogenic cell death. J. Immunother. Cancer 2020, 8, e000337. [CrossRef]

250. Galassi, C.; Manic, G.; Musella, M.; Sistigu, A.; Vitale, I. Assessment of IFN-gamma and granzyme-B production by in sitro technology. Methods Enzymol. 2020, 631, 391-414. [CrossRef]

251. De Ninno, A.; Bertani, F.R.; Gerardino, A.; Schiavoni, G.; Musella, M.; Galassi, C.; Mattei, F.; Sistigu, A.; Businaro, L. Microfluidic co-culture models for dissecting the immune response in in vitro tumor microenvironments. J. Vis. Exp. 2021, 170. [CrossRef]

252. Vacchelli, E.; Sistigu, A.; Yamazaki, T.; Vitale, I.; Zitvogel, L.; Kroemer, G. Autocrine signaling of type 1 interferons in successful anticancer chemotherapy. Oncoimmunology 2015, 4, e988042. [CrossRef]

253. Stagg, J.; Loi, S.; Divisekera, U.; Ngiow, S.F.; Duret, H.; Yagita, H.; Teng, M.W.; Smyth, M.J. Anti-ErbB-2 mAb therapy requires type I and II interferons and synergizes with anti-PD-1 or anti-CD137 mAb therapy. Proc. Natl. Acad. Sci. USA 2011, 108, 7142-7147. [CrossRef]

254. Yang, X.; Zhang, X.; Fu, M.L.; Weichselbaum, R.R.; Gajewski, T.F.; Guo, Y.; Fu, Y.X. Targeting the tumor microenvironment with interferon-beta bridges innate and adaptive immune responses. Cancer Cell 2014, 25, 37-48. [CrossRef] [PubMed]

255. Bracci, L.; Sistigu, A.; Proietti, E.; Moschella, F. The added value of type I interferons to cytotoxic treatments of cancer. Cytokine Growth Factor Rev. 2017, 36, 89-97. [CrossRef] [PubMed]

256. Burnette, B.C.; Liang, H.; Lee, Y.; Chlewicki, L.; Khodarev, N.N.; Weichselbaum, R.R.; Fu, Y.X.; Auh, S.L. The efficacy of radiotherapy relies upon induction of type i interferon-dependent innate and adaptive immunity. Cancer Res. 2011, 71, 2488-2496. [CrossRef]

257. Deng, L.; Liang, H.; Xu, M.; Yang, X.; Burnette, B.; Arina, A.; Li, X.D.; Mauceri, H.; Beckett, M.; Darga, T.; et al. STING-dependent cytosolic DNA sensing promotes radiation-induced type I interferon-dependent antitumor immunity in immunogenic tumors. Immunity 2014, 41, 843-852. [CrossRef]

258. Gresser, I.; Bourali, C. Exogenous interferon and inducers of interferon in the treatment Balb-c mice inoculated with RC19 tumour cells. Nature 1969, 223, 844-845. [CrossRef] [PubMed] 
259. Arico, E.; Castiello, L.; Capone, I.; Gabriele, L.; Belardelli, F. Type I interferons and cancer: An evolving story demanding novel clinical applications. Cancers 2019, 11, 1943. [CrossRef] [PubMed]

260. Eggermont, A.M.; Suciu, S.; Testori, A.; Santinami, M.; Kruit, W.H.; Marsden, J.; Punt, C.J.; Sales, F.; Dummer, R.; Robert, C.; et al. Long-term results of the randomized phase III trial EORTC 18991 of adjuvant therapy with pegylated interferon alfa- $2 \mathrm{~b}$ versus observation in resected stage III melanoma. J. Clin. Oncol. 2012, 30, 3810-3818. [CrossRef]

261. Moschos, S.J.; Edington, H.D.; Land, S.R.; Rao, U.N.; Jukic, D.; Shipe-Spotloe, J.; Kirkwood, J.M. Neoadjuvant treatment of regional stage IIIB melanoma with high-dose interferon alfa- $2 \mathrm{~b}$ induces objective tumor regression in association with modulation of tumor infiltrating host cellular immune responses. J. Clin. Oncol. 2006, 24, 3164-3171. [CrossRef]

262. Burchert, A.; Muller, M.C.; Kostrewa, P.; Erben, P.; Bostel, T.; Liebler, S.; Hehlmann, R.; Neubauer, A.; Hochhaus, A. Sustained molecular response with interferon alfa maintenance after induction therapy with imatinib plus interferon alfa in patients with chronic myeloid leukemia. J. Clin. Oncol. 2010, 28, 1429-1435. [CrossRef]

263. Preudhomme, C.; Guilhot, J.; Nicolini, F.E.; Guerci-Bresler, A.; Rigal-Huguet, F.; Maloisel, F.; Coiteux, V.; Gardembas, M.; Berthou, C.; Vekhoff, A.; et al. Imatinib plus peginterferon alfa-2a in chronic myeloid leukemia. N. Engl. J. Med. 2010, 363, 2511-2521. [CrossRef] [PubMed]

264. Riley, C.H.; Hansen, M.; Brimnes, M.K.; Hasselbalch, H.C.; Bjerrum, O.W.; Straten, P.T.; Svane, I.M.; Jensen, M.K. Expansion of circulating CD56bright natural killer cells in patients with JAK2-positive chronic myeloproliferative neoplasms during treatment with interferon-alpha. Eur. J. Haematol. 2015, 94, 227-234. [CrossRef]

265. Simonsson, B.; Gedde-Dahl, T.; Markevarn, B.; Remes, K.; Stentoft, J.; Almqvist, A.; Bjoreman, M.; Flogegard, M.; Koskenvesa, P.; Lindblom, A.; et al. Combination of pegylated IFN-alpha2b with imatinib increases molecular response rates in patients with low- or intermediate-risk chronic myeloid leukemia. Blood 2011, 118, 3228-3235. [CrossRef] [PubMed]

266. Ribas, A.; Wolchok, J.D. Cancer immunotherapy using checkpoint blockade. Science 2018, 359, 1350-1355. [CrossRef]

267. Jenkins, R.W.; Barbie, D.A.; Flaherty, K.T. Mechanisms of resistance to immune checkpoint inhibitors. Br. J. Cancer 2018, 118, 9-16. [CrossRef]

268. Shin, D.S.; Zaretsky, J.M.; Escuin-Ordinas, H.; Garcia-Diaz, A.; Hu-Lieskovan, S.; Kalbasi, A.; Grasso, C.S.; Hugo, W.; Sandoval, S.; Torrejon, D.Y.; et al. Primary resistance to PD-1 blockade mediated by JAK1/2 mutations. Cancer Discov. 2017, 7, 188-201. [CrossRef] [PubMed]

269. Wang, X.; Schoenhals, J.E.; Li, A.; Valdecanas, D.R.; Ye, H.; Zang, F.; Tang, C.; Tang, M.; Liu, C.G.; Liu, X.; et al. Suppression of type I IFN signaling in tumors mediates resistance to anti-PD-1 treatment that can be overcome by radiotherapy. Cancer Res. 2017, 77, 839-850. [CrossRef]

270. Zaretsky, J.M.; Garcia-Diaz, A.; Shin, D.S.; Escuin-Ordinas, H.; Hugo, W.; Hu-Lieskovan, S.; Torrejon, D.Y.; Abril-Rodriguez, G.; Sandoval, S.; Barthly, L.; et al. Mutations associated with acquired resistance to PD-1 blockade in melanoma. N. Engl. J. Med. 2016, 375, 819-829. [CrossRef]

271. Sceneay, J.; Goreczny, G.J.; Wilson, K.; Morrow, S.; DeCristo, M.J.; Ubellacker, J.M.; Qin, Y.; Laszewski, T.; Stover, D.G.; Barrera, V.; et al. Interferon signaling is diminished with age and is associated with immune checkpoint blockade efficacy in triple-negative breast cancer. Cancer Discov. 2019, 9, 1208-1227. [CrossRef]

272. Tarhini, A.A.; Cherian, J.; Moschos, S.J.; Tawbi, H.A.; Shuai, Y.; Gooding, W.E.; Sander, C.; Kirkwood, J.M. Safety and efficacy of combination immunotherapy with interferon alfa-2b and tremelimumab in patients with stage IV melanoma. J. Clin. Oncol. 2012, 30, 322-328. [CrossRef]

273. Kochenderfer, J.N.; Rosenberg, S.A. Treating B-cell cancer with T cells expressing anti-CD19 chimeric antigen receptors. Nat. Rev. Clin. Oncol. 2013, 10, 267-276. [CrossRef]

274. Rosenberg, S.A.; Yang, J.C.; Sherry, R.M.; Kammula, U.S.; Hughes, M.S.; Phan, G.Q.; Citrin, D.E.; Restifo, N.P.; Robbins, P.F.; Wunderlich, J.R.; et al. Durable complete responses in heavily pretreated patients with metastatic melanoma using T-cell transfer immunotherapy. Clin. Cancer Res. 2011, 17, 4550-4557. [CrossRef]

275. Robb, R.J.; Kreijveld, E.; Kuns, R.D.; Wilson, Y.A.; Olver, S.D.; Don, A.L.; Raffelt, N.C.; De Weerd, N.A.; Lineburg, K.E.; Varelias, A.; et al. Type I-IFNs control GVHD and GVL responses after transplantation. Blood 2011, 118, 3399-3409. [CrossRef]

276. Katlinski, K.V.; Gui, J.; Katlinskaya, Y.V.; Ortiz, A.; Chakraborty, R.; Bhattacharya, S.; Carbone, C.J.; Beiting, D.P.; Girondo, M.A.; Peck, A.R.; et al. Inactivation of interferon receptor promotes the establishment of immune privileged tumor microenvironment. Cancer Cell 2017, 31, 194-207. [CrossRef] [PubMed]

277. Saxena, M.; van der Burg, S.H.; Melief, C.J.M.; Bhardwaj, N. Therapeutic cancer vaccines. Nat. Rev. Cancer 2021, 21, 360-378. [CrossRef] [PubMed]

278. Fu, J.; Kanne, D.B.; Leong, M.; Glickman, L.H.; McWhirter, S.M.; Lemmens, E.; Mechette, K.; Leong, J.J.; Lauer, P.; Liu, W.; et al. STING agonist formulated cancer vaccines can cure established tumors resistant to PD-1 blockade. Sci. Transl. Med. 2015, 7, 283ra252. [CrossRef] [PubMed]

279. Miquilena-Colina, M.E.; Lozano-Rodriguez, T.; Garcia-Pozo, L.; Saez, A.; Rizza, P.; Capone, I.; Rapicetta, M.; Chionne, P.; Capobianchi, M.; Selleri, M.; et al. Recombinant interferon-alpha2b improves immune response to hepatitis $B$ vaccination in haemodialysis patients: Results of a randomised clinical trial. Vaccine 2009, 27, 5654-5660. [CrossRef]

280. Urbani, F.; Ferraresi, V.; Capone, I.; Macchia, I.; Palermo, B.; Nuzzo, C.; Torsello, A.; Pezzotti, P.; Giannarelli, D.; Pozzi, A.F.; et al. Clinical and immunological outcomes in high-risk resected melanoma patients receiving peptide-based vaccination and interferon alpha, with or without dacarbazine preconditioning: A phase II study. Front. Oncol. 2020, 10, 202. [CrossRef] 
281. Geoffroy, K.; Bourgeois-Daigneault, M.C. The pros and cons of interferons for oncolytic virotherapy. Cytokine Growth Factor Rev. 2020, 56, 49-58. [CrossRef] [PubMed]

282. Melero, I.; Quetglas, J.I.; Reboredo, M.; Dubrot, J.; Rodriguez-Madoz, J.R.; Mancheno, U.; Casales, E.; Riezu-Boj, J.I.; Ruiz-Guillen, M.; Ochoa, M.C.; et al. Strict requirement for vector-induced type I interferon in efficacious antitumor responses to virally encoded IL12. Cancer Res. 2015, 75, 497-507. [CrossRef]

283. Bhattacharya, S.; HuangFu, W.C.; Dong, G.; Qian, J.; Baker, D.P.; Karar, J.; Koumenis, C.; Diehl, J.A.; Fuchs, S.Y. Anti-tumorigenic effects of type 1 interferon are subdued by integrated stress responses. Oncogene 2013, 32, 4214-4221. [CrossRef] [PubMed]

284. Huangfu, W.C.; Qian, J.; Liu, C.; Liu, J.; Lokshin, A.E.; Baker, D.P.; Rui, H.; Fuchs, S.Y. Inflammatory signaling compromises cell responses to interferon alpha. Oncogene 2012, 31, 161-172. [CrossRef]

285. Zheng, H.; Qian, J.; Carbone, C.J.; Leu, N.A.; Baker, D.P.; Fuchs, S.Y. Vascular endothelial growth factor-induced elimination of the type 1 interferon receptor is required for efficient angiogenesis. Blood 2011, 118, 4003-4006. [CrossRef]

286. Tomita, S.; Ishibashi, K.; Hashimoto, K.; Sugino, T.; Yanagida, T.; Kushida, N.; Shishido, K.; Aikawa, K.; Sato, Y.; Suzutani, T.; et al. Suppression of SOCS3 increases susceptibility of renal cell carcinoma to interferon-alpha. Cancer Sci. 2011, 102, 57-63. [CrossRef] [PubMed]

287. Landolfo, S.; Guarini, A.; Riera, L.; Gariglio, M.; Gribaudo, G.; Cignetti, A.; Cordone, I.; Montefusco, E.; Mandelli, F.; Foa, R. Chronic myeloid leukemia cells resistant to interferon-alpha lack STAT1 expression. Hematol. J. 2000, 1, 7-14. [CrossRef]

288. Romero-Weaver, A.L.; Wang, H.W.; Steen, H.C.; Scarzello, A.J.; Hall, V.L.; Sheikh, F.; Donnelly, R.P.; Gamero, A.M. Resistance to IFN-alpha-induced apoptosis is linked to a loss of STAT2. Mol. Cancer Res. 2010, 8, 80-92. [CrossRef]

289. Bi, X.; Hameed, M.; Mirani, N.; Pimenta, E.M.; Anari, J.; Barnes, B.J. Loss of interferon regulatory factor 5 (IRF5) expression in human ductal carcinoma correlates with disease stage and contributes to metastasis. Breast Cancer Res. 2011, 13, R111. [CrossRef] [PubMed]

290. Bidwell, B.N.; Slaney, C.Y.; Withana, N.P.; Forster, S.; Cao, Y.; Loi, S.; Andrews, D.; Mikeska, T.; Mangan, N.E.; Samarajiwa, S.A.; et al. Silencing of Irf7 pathways in breast cancer cells promotes bone metastasis through immune escape. Nat. Med. 2012, 18, 1224-1231. [CrossRef]

291. Zhao, Y.; Chen, W.; Zhu, W.; Meng, H.; Chen, J.; Zhang, J. Overexpression of interferon regulatory factor 7 (IRF7) reduces bone metastasis of prostate cancer cells in mice. Oncol. Res. 2017, 25, 511-522. [CrossRef]

292. Minn, A.J. Interferons and the immunogenic effects of cancer therapy. Trends Immunol. 2015, 36, 725-737. [CrossRef]

293. Khodarev, N.N.; Beckett, M.; Labay, E.; Darga, T.; Roizman, B.; Weichselbaum, R.R. STAT1 is overexpressed in tumors selected for radioresistance and confers protection from radiation in transduced sensitive cells. Proc. Natl. Acad. Sci. USA 2004, 101, 1714-1719. [CrossRef] [PubMed]

294. Tsai, M.H.; Cook, J.A.; Chandramouli, G.V.; DeGraff, W.; Yan, H.; Zhao, S.; Coleman, C.N.; Mitchell, J.B.; Chuang, E.Y. Gene expression profiling of breast, prostate, and glioma cells following single versus fractionated doses of radiation. Cancer Res. 2007, 67, 3845-3852. [CrossRef] [PubMed]

295. Boelens, M.C.; Wu, T.J.; Nabet, B.Y.; Xu, B.; Qiu, Y.; Yoon, T.; Azzam, D.J.; Twyman-Saint, C.V.; Wiemann, B.Z.; Ishwaran, H.; et al. Exosome transfer from stromal to breast cancer cells regulates therapy resistance pathways. Cell 2014, 159, 499-513. [CrossRef]

296. Gaston, J.; Cheradame, L.; Yvonnet, V.; Deas, O.; Poupon, M.F.; Judde, J.G.; Cairo, S.; Goffin, V. Intracellular STING inactivation sensitizes breast cancer cells to genotoxic agents. Oncotarget 2016, 7, 77205-77224. [CrossRef] [PubMed] 